\title{
THE RIGHTS OF THE MENTALLY ILL UNDER STATE CONSTITUTIONS
}

\author{
Alan MeISEL*
}

\author{
I \\ Toward a More Viable Source of Rights for the Mentally \\ Ill: A CRITIQUe of EXISTING Case LaW
}

The decade of the 1970's witnessed substantial lawmaking activity aimed at securing the liberties of persons in the mental health process. Although some of the lawmaking occurred in the legislative and regulatory spheres, the courts have been the primary forum for this activity, and have often prodded the legislatures ${ }^{1}$ and regulatory agencies into action. ${ }^{2}$

To a large extent, the source of these expanded rights and the basis for decision in the case law has been, especially in the earlier years of litigation, various provisions of the U.S. Constitution. More recently, and in light of the increased legislation in this area, an increasing number of cases have been decided on the basis of federal statutory and regulatory law. ${ }^{3}$

The trial court cases have been subjected to appellate review, and on occasion the appellate cases from the federal courts of appeal and the state supreme courts have been granted review by the Supreme Court. Not until 1975, however, did the U.S. Supreme Court first hear and decide a case involving the rights of individuals

\footnotetext{
Copyright (C) 1983 by Alan Meisel

* Professor of Law and Psychiatry, University of Pittsburgh School of Law and Department of Psychiatry (Western Psychiatric Institute and Clinic), University of Pittsburgh School of Medicine.

I am indebted to Debra McCloskey Barnhart, Richard Boyle, and David Baxter, who, as law students, provided invaluable research assistance. I have also benefited greatly from discussions about state constitutional law with Professor Robert F. Williams of Rutgers (Camden) School of Law. This work was supported in part by grants from the Foundations Fund for Research in Psychiatry and the National Institute for Mental Health (CRC Grant No. MH30915), by Western Psychiatric Institute and Clinic, and by a Faculty Research Stipend from the University of Pittsburgh School of Law.

1. See, e.g., Goldy v. Beal, 429 F. Supp. 640 (M.D. Pa. 1976) (three-judge court), in which the federal district court declared unconstitutional the key provision of the Pennsylvania civil commitment statute The next day, the Pennsylvania legislature enacted and the governor signed a new civil commitment bill which had been before the legislature for about a year, and predecessors of which had been debated for several years.

2. See, e.g., Bartley v. Kremens, 402 F. Supp. 1039 (E.D. Pa. 1975) (three-judge court), where the filing of the complaint prompted the Pennsylvania Department of Public Welfare to promulgate regulations to correct the deficiencies alleged to exist in the statutory procedures for the hospitalization of children. See Additional Procedural Safeguards for Juveniles Admilted to Institutions Pursuant to $\$ \$ 402$ and 403 of the Mental Health and Mental Retardation Act, 3 Pa. Admin. Bull. 536 (1973).

3. The most important federal legislation is the Developmentally Disabled Assistance and Bill of Rights Act of 1975, 42 U.S.C. $\S \S 6001-6081$ (1976 \& Supp. II 1978). Other significant statutes are the Rehabilitation Act of 1973, 29 U.S.C. $\$ \$ 701-794$ (1976 \& Supp. II 1978); the Education for All Handicapped Children Act of 1975, 20 U.S.C. $\$ \S 1401-1461$ (1976 \& Supp. III 1979); Social Security Amendment of 1974, 42 U.S.C. $\$ \S 1396 d(d), 1397$ (1976 \& Supp. III 1979); Community Mental Health Centers Act, 42 U.S.C. $§ 2689$ (1976 \& Supp. II 1978); Mental Health Systems Act, Pub. L. No. 96-398 (1980). Whether or not these statutes create private rights of action is unsettled. See infra note 145.
} 
on the civil side of the mental health system. ${ }^{4}$ Since that time it has decided three others. $^{5}$

From this small but continually growing number of cases, and from an equally small number of cases construing federal statutes, ${ }^{6}$ one thing is clear: the Court has not been willing to read the Constitution as expansively as have the lower federal and state supreme courts in adjudicating the rights of individuals in the mental health process. ${ }^{7}$ In addition, during this same period the Court has decided four cases involving the rights of mentally or physically handicapped persons based on federal statute, and in all has shown a disinclination to support these rights vigorously. ${ }^{8}$ The grounds for decision in these four statutory cases seemingly had nothing to do with the fact that handicapped persons were involved. Rather, they were decided on more neutral "legal" principles involving matters of statutory construction and legislative intent. Indeed, one of the "constitutional" cases" was also decided, ostensibly, on principles having nothing to do with mental health or illness. ${ }^{10}$ Nonetheless, when read together, these eight cases and the numerous others in which the Court either summarily affirmed or denied review do not bode well for the rights of civilly committed ${ }^{11}$ mentally ill persons. ${ }^{12}$ The

4. See O'Connor v. Donaldson, 422 U.S. 563 (1975). See also infra note 24.

5. See Youngberg v. Romeo, 102 S. Ct. 2452 (1982); Parham v. J.R., 442 U.S. 584 (1979); Addington v. Texas, 441 U.S. 418 (1979). In addition to these cases which were decided on the merits, there are a number of other cases in which the Court has disposed of the case on nonsubstantive grounds, has denied review, or has disposed of the substantive mental health issues summarily. See infra note 24. Parham was eventually argued and decided with a companion case, Secretary of Pub. Welfare v. Institutionalized Juveniles, 442 U.S. 640 (1979), which had previously been argued and decided by the Court on a procedural issue sub nom. Kremens v. Bartley, 431 U.S. 119 (1977). See infra note 46. Mills v. Rogers, 102 S. Ct. 2442 (1982), was remanded in light of subsequent state law developments. See infra note 17.

6. Pennhurst State School \& Hosp. v. Halderman, 451 U.S. 1 (1981).

The Court has also not been hospitable to similar kinds of claims involving the rights of the physically handicapped. See Hendrick Hudson Cent. School Dist. Bd. of Educ. v. Rowley, 102 S. Ct. 3034 (1982); Southeastern Community College v. Davis, 442 U.S. 397 (1979); University of Texas v. Camenisch, 449 U.S. 950 (1981).

7. In two of the cases, Donaldson and Parham, the Court rejected the opinions and holdings of the lower courts. See infra text accompanying notes 20-29, 44-52. By contrast, in Addington, the Court's holding was more protective of the rights of the mentally ill than the lower court, but not as protective as it might have been. See infra text accompanying notes $36-43$.

8. See supra note 6 .

9. O'Connor v. Donaldson, 422 U.S. 563 (1975). In this case, the Court declined to reach the "broad" constitutional issue on which the case had turned in the district court and the court of appeals, deciding it instead on narrower constitutional grounds. See infra text accompanying note 29. Whether or not the petitioner's status as a patient in a state mental hospital influenced the court to decide the case on narrower grounds is impossible to know.

10. The opinions and grounds for decision in the other two "constitutional" cases, Parharn v. J.R., 422 U.S. 584 (1979), and Addington v. Texas, 441 U.S. 418 (1979), were both manifestly influenced by the fact that the questions involved mentally ill persons.

11. The same cannot necessarily be said about mentally ill persons in the criminal process. The Court, in Vitek v. Jones, 445 U.S. 480 (1980), demonstrated a continuing receptivity to claims of constitutional violations brought by persons who have entered the mental health system via the criminal process. This trend was started in Baxstrom v. Herold, 387 U.S. 107 (1966), and underscored in Jackson v. Indiana, 406 U.S. 715 (1972). For a discussion of the differences between the civil and criminal sides of the mental health system, see infra notes 22-23.

12. There is some additional support for the notion that the present majority of the Court, and especially the Chief Justice, is ill-disposed toward the rights of the mentally ill in general. Justice Blackmun's concurring opinion in Pennhurst State School \& Hosp. v. Halderman, 451 U.S. 1 (1981), suggests as much:

I do not join the Court's advisory discussion in Part IV of its opinion. In that Part, the Court properly 
Court's summary dispositions-denials of certiorari ${ }^{13}$ and summary affirmances ${ }^{14}$ —of cases in which the lower courts had ruled adversely to the claims presented by mental patients further evidences the Court's disinclination to indulge in an expansive application of constitutional rights to those in the civil mental health system.

In light of the Court's unwillingness to proceed as far and as fast as the lower courts, many advocates for the mentally ill might well have reason to despair over being caught in a "holding action" until the political climate changes. An attitude of that sort is shortsighted and unduly pessimistic. A virtually untapped source of rights exists in every state: the state constitution. There is, of course, also state statutory, regulatory, and case law upon which litigants can draw; but unlike the forgotten state constitutions, these other sources of legal principles have been actively invoked in mental health litigation. To date, only a few significant cases involving the rights of persons on the civil side of the mental health process have been decided on the basis of state constitutional provisions. In light of the Supreme Court's record first on constitutional grounds and more recently on statutory grounds, state constitutional provisions may be the most promising source of rights for the mentally ill in the decade of the 1980's. ${ }^{15}$ Whether or not the Supreme Court will continue this trend is a question left unanswered during the 1981 Term, when the Court heard argument in and decided two ${ }^{16}$ important

and correctly notes, ante, at 26 , that it leaves open for consideration on remand whether, and in what form, $\$ \S 6011$ and 6063 create rights that are enforceable by private parties like those that make up these plaintiff classes. The Court, however, seems to me strongly to intimate that it will not view kindly any future positive holding in that direction. I agree that this specific question was not presented and is not today decided, but I decline to join what appears to be a negative attitude on the part of the Court to what is a possible construction of the [Developmental Disabilities Assistance and Bill of Rights] Act.

Id. at 32. See also infro note 32 .

13. See infra note 24 .

14. See, e.g., Legion v. Richardson, 354 F. Supp. 456 (S.D.N.Y.) (three-judge court), affd sub nom. Legion v. Weinberger, 414 U.S. 1058 (1973) (mem. opinion), reh'g denied, 415 U.S. 939 (1974), involving a challenge to the constitutionality of Medicare and Medicaid provisions of the Social Security Act which limit benefits to persons receiving psychiatric care in state hospitals; Woe v. Mathews, 408 F. Supp. 419 (E.D.N.Y. 1976), modified, 556 F.2d 563 (2d Cir. 1977), affd sub nom. Woe v. Weinberger, 562 F.2d 40 (2d Cir. 1977) (mem. opinion), cert. denied sub nom. Woe v. Califano, 434 U.S. 1048 (1978), raising claims similar to those in Legion v. Richardson, supro, and additionally claiming that there is a constitutionally based right to treatment which entitles one to treatment in a general hospital rather than a psychiatric hospital.

More recently, the Court has dealt with related issues on the merits and upheld the constitutionality of a provision of the Social Security Act denying SSI benefits to residents of public mental institutions on the ground that the "statute does not classify directly on the basis of mental health." Schweiker v. Wilson, 450 U.S. 221 (1981). The Court noted, however, that the level of scrutiny required when legislation does classify on the basis of mental illness remains an open question. Id. n.13.

The Court has also summarily affirmed lower court rulings rejecting challenges to the constitutionality of state involuntary civil commitment procedures. The most recent is French v. Blackburn, 443 U.S. 901 (1979) (mem. opinion), affg 428 F. Supp. 1351 (M.D.N.C. 1977) (three-judge court). An earlier case, predating the Court's post-1975 mental health decisions, is Briggs v. Arafeh, 411 U.S. 911 (1973) (mem. opinion), affg Logan v. Arafeh, 346 F. Supp. 1265 (D. Conn. 1972) (three-judge court).

15. State constitutions are increasingly being examined in other contexts too. See generally Developments in the Law-The Interpretation of State Constitutional Rights, 95 HARV. L. REV. 1193 (1982); Margolick, State Judiciaries Are Shaping Law That Goes Beyond Supreme Court, N.Y. Times, May 19, 1982, at Al, col. 1 (city ed.); Margolick, On Liberal Law in the Reagan Era, N.Y. Times, Dec. 10, 1981, at B1, col. 3.

16. In a third case, Rennie v. Klein, $102 \mathrm{~S}$. Ct. 3506 (1982), the Court remanded to the Third Circuit for reconsideration in light of the holding in Youngberg v. Romeo, $102 \mathrm{~S}$. Ct. 2452 (1982). 
cases, Mills $v$. Rogers ${ }^{17}$ and Youngberg v. Romeo ${ }^{18}$ Mills was remanded for reconsideration in light of a clarification of state law subsequent to the court of appeals' opinion, ${ }^{19}$ and although Youngberg was heralded by the popular press as establishing a federal constitutional right to treatment for the institutionalized mentally retarded, it is a limited holding.

O'Connor v. Donaldson, ${ }^{20}$ decided by the Supreme Court in 1975, was the first "civil" mental health case to reach the Court on the merits. All previous cases involved persons who had first been involved in the criminal process, and then been diverted to the mental health system either because of incompetency to stand trial $^{21}$ or commitment after conviction to a "therapeutic," rather than punitive, setting. ${ }^{22}$ Furthermore, the Court had reviewed some civil mental health cases,

17. Mills, $102 \mathrm{~S}$. Ct. 2442 (1982), raises one of the most significant mental health issues of the last decade which will continue to be important in the 1980's: the right of involuntarily committed patients to refuse treatment. In the several cases to date dealing with this issue, all of the lower federal and state courts have held that a rather broad, though not absolute, right exists. See Rennie v. Klein, 653 F.2d 836 (3d Cir. 1981); Davis v. Hubbard, No. C-73-205 (N.D. Ohio Sept. 16, 1980); Colyar v. Third Judicial Dist. Court, 469 F. Supp. 424 (D. Utah 1979); In re K.K.B., 609 P.2d 747 (Okla. 1980). Compare A.E. v. Mitchell, No. C. 78-466 (D. Utah 1980) (rejecting a constitutional right to refuse medications on the basis that a new Utah statute requires a judicial finding that "the patient lacks the ability to engage in a rational decisionmaking process regarding the acceptance of mental treatment as demonstrated by evidence of inability to weigh the possible costs and benefits of treatment").

18. 102 S. Ct. 2452 (1982). Romeo raises a variety of questions concerning the right to treatment, and thus to some extent revives the issue which the Court avoided in Donaldson. Romeo also presents an additional issue dealing with the "least restrictive alternative" principle, a principle which has been ruled upon far more frequently in the lower courts and generally in a way favorable to patients. See infra note 116.

19. See In re Roe, 421 N.E.2d 40 (Mass. 1981).

20. 422 U.S. 563 (1975), vacating and remanding, 493 F.2d 507 (5th Cir. 1974).

21. In a landmark case, Jackson v. Indiana, 406 U.S. 715 (1972), the Court held unconstitutional an Indiana statute, which permitted one found incompetent to stand trial to be held indefinitely in a psychiatric hospital, as offending the due process clause of the 14th amendment. Some years earlier, the Court had upheld the constitutionality of the federal incompetency statute, 18 U.S.C. $\$ \S 4244-4248$ (1949), in Greenwood v. United States, 350 U.S. 366 (1956).

22. Individuals may also enter the mental health system from the criminal system after conviction for a crime, either immediately after conviction and in lieu of imprisonment or upon completion of the term of imprisonment. The Court has decided several cases in the first category. Humphrey v. Cady, 405 U.S. 504 (1974), involved a conviction for the crime of contributing to the delinquency of a minor, which carried a maximum one-year sentence. However, the petitioner was, in lieu of sentence, committed to the "sex deviate facility" pursuant to the Wisconsin Sex Crimes Act, which allowed commitment for a period (renewable every five years) equal to the maximum sentence for the crime. The Court held that on remand the court could find that petitioner had been denied the equal protection of the law because the renewal proceeding is essentially equivalent to Wisconsin's involuntary civil commitment procedure, which requires a jury determination. Specht v. Patterson, 386 U.S. 605 (1967), involved a commitment of an individual convicted for "indecent liberties." Under the Colorado Sex Offender's Act, one convicted of a sexual offense could be indefinitely committed in lieu of sentence. Because commitment under the Act requires a new finding of fact beyond those necessary for the underlying criminal conviction, the Court held that due process requires that the petitioner be afforded certain elementary procedural safeguards. In a third such case, Murel v. Baltimore City Criminal Court, 407 U.S. 355 (1972), in light of substantial revisions taking place in Maryland civil commitment statutes, the Court dismissed as improvidently granted a writ of certiorari. In that case, petitioners were committed as "defective delinquents" after being convicted for various criminal offenses. In a companion case, however, McNeil v. Director, Patuxent Inst., 407 U.S. 245 (1972), the Court granted relief to an individual committed for observation to determine whether he was a "defective delinquent" who refused to cooperate with psychiatrists in this determination. As a result, he was held in a psychiatric hospital for the duration of his five-year sentence, and he brought a petition for habeas corpus on the expiration of his sentence when the state refused to release him. The Court granted 
but decided them on procedural grounds ${ }^{23}$ or summarily denied review or affirmed. ${ }^{24}$

Kenneth Donaldson, who had been committed to Chatahoochee State Hospital in Florida in 1957 and released 141/2 years later after filing 18 suits seeking his release, ${ }^{25}$ submitted a petition for habeas corpus in federal district court seeking release from the hospital, as well as declaratory, injunctive, and compensatory relief, ${ }^{26}$ on the ground that he had been denied treatment which was constitutionally guaranteed to him under the 14th amendment. ${ }^{27}$ Despite its novelty, the court permitted the claim for damages to go to the jury, which found in his favor against two of the five defendants. On appeal, the Fifth Circuit affirmed in a farreaching opinion which elaborated a constitutional theory of the right to treatment. ${ }^{28}$ Although the Court declined to reach the right-to-treatment issue

relief on the ground that such a long commitment, made only on an ex parte basis, was a denial of due process.

The final means of entry into the mental health system from the criminal system involves persons for whom, on the expiration of their prison term, the authorities seek a continuation of confinement because of mental illness. The most important case in this area is Baxstrom v. Herold, 383 U.S. 107 (1966), which held that the petitioner was denied equal protection when, at the termination of his prison sentence, he was committed to a psychiatric ward in the prison pursuant to procedures different from those afforded in an ordinary civil commitment proceeding.

23. Prior to 1975, the Court had decided some mental health cases on procedural points. See, e.g., Lessard v. Schmidt, 349 F. Supp. 1078 (E.D. Wis. 1972) (three-judge court), vacated and remanded on other grounds, 414 U.S. 473 (1974), on remand, 379 F. Supp. 1376 (E.D. Wis. 1974), vacated and remanded on other grounds, 421 U.S. 957 (1975), on remand, 413 F. Supp. 1318 (E.D. Wis. 1976); Bartley v. Kremens, 402 F. Supp. 1039 (E.D. Pa. 1975) (three-judge court), vacaled and remanded, 431 U.S. 119 (1977), which was subsequently decided by the, Court sub nom. Secretary of Pub. Welfare v. Institutionalized Juveniles, 442 U.S. 640 (1979). See infra note 46.

24. Between the 1970 Term and the decision in $O^{\prime}$ Connor $v$. Donaldson in the 1974 Term, there were numerous denials of certiorari in cases involving mental health issues. See, e.g., Haldane v. Ruppe, 402 U.S. 906 (1971) (civil rights action against judicial officers and attorneys involving state procedures for examination of allegedly mentally ill persons); Fhagen v. Miller, 409 U.S. 845 (1972) (constitutionality of New York emergency commitment procedures); Robinson v. McCorkle, 409 U.S. 1042 (1979) (constitutionality of New Jersey emergency commitment procedures); Graham v. United States, 410 U.S. 983 (1973) (damage suit against attorney general for wrongful commitment and treatment); Lausche $v$. Commissioner of Pub. Welfare, 420 U.S. 993 (1975) (constitutionality of commitment criteria and preponderance of evidence standard of proof); Winters v. Miller, 404 U.S. 985 (1971) (right of involuntarily committed patient to refuse psychiatric treatment).

At least one case was summarily affirmed. See Briggs v. Arafeh, 411 U.S. 911 (1973) (constitutionality of Connecticut emergency commitment procedures).

In addition, the Supreme Court had declined to review Kenneth Donaldson's claim four times before the 1975 decision. See Donaldson v. O'Connor, 400 U.S. 869 (1970); Donaldson v. O'Connor, 390 U.S. 971 (1968); Donaldson v. Florida, 371 U.S. 806 (1963); In re Donaldson, 369 U.S. 808 (1960).

25. B. Ennis, Prisoners of Psychiatry 89 (1972).

26. Because Donaldson was released from the hospital shortly after filing suit - which was probably not related to the filing of suit since he had filed suit on numerous prior occasions-he dropped all his claims except those relating to damages.

27. Donaldson had previously filed 18 other actions, four of which had been denied review by the Supreme Court. See supra note 24. See Note, Donaldson, Dangerousness, and the Right to Treatment, 3 HASTINGS CONST. L.Q. 599 (1976).

28. 493 F.2d 507 (5th Cir. 1974). The notion of a constitutionally based right to treatment had previously been accepted by at least one other federal district court besides the one which had ruled in Donaldson's favor, see Wyatt v. Stickney, 325 F. Supp. 1305 (M.D. Ala. 1971), but without any explanation of the theory underlying the right. In addition, at least two federal district courts had rejected such a right. See Burnham v. Department of Pub. Health, 349 F. Supp. 1335 (N.D. Ga. 1972); New York Ass'n for Retarded Children, Inc. v. Rockefeller, 357 F. Supp. 752 (E.D.N.Y. 1973). Shortly after the Fifth Circuit's 
addressed in the courts below, ${ }^{29}$ it did hold that Donaldson's continued confinement was not constitutionally justified and that he was entitled to damages for the deprivation of his liberty unless the defendants were immune from liability.

For present purposes, what is most significant about the decision is not what it held-for in a sense the opinion can be considered quite protective of the rights of involuntarily civilly committed psychiatric patients-but what it failed to hold. The Court did not merely remand, it vacated the judgment of the Fifth Circuit, not only rejecting it for having reached broad constitutional issues but also explicitly underscoring that its holding "vacating the judgment of the Court of Appeals deprives that court's opinion of precedential effect, leaving this Court's opinion and judgment as the sole law of the case."30

To date, the Court has not definitively settled the question of whether or not the Constitution secures a right to treatment, and if so what its boundaries are. ${ }^{31}$ Clearly, the Court was less than sympathetic to a constitutionally based right to treatment, and it is possible that the Court would have reached the question had it been able to muster a majority. The existing evidence, however, suggests that the Court was badly splintered on the issue, ${ }^{32}$ and for that reason chose to decide the

decision in the $O^{\prime}$ Connor case, it also affirmed the decision of the district court in Wyatt $v$. Stickney. See Wyatt v. Aderholt, 503 F.2d 1305 (5th Cir. 1974).

Significant cases decided prior to $O^{\prime}$ Connor which found a right to treatment are Rouse v. Cameron, 373 F.2d 451 (D.C. Cir. 1966) (statutory basis); Davis v. Watkins, 384 F. Supp. 1196 (N.D. Ohio 1974) (interim order), opinion handed down sub nom. Davis v. Balson, 461 F. Supp. 842 (N.D. Ohio 1978) (three-judge court) (criminally insane persons); Welsch v. Likins, 373 F. Supp. 487 (D. Minn. 1974), affd in part, vacated and remanded in part, 550 F.2d 1122 (8th Cir. 1977); Nason v. Superintendent of Bridgewater State Hosp., 353 Mass. 604, 233 N.E.2d 908 (1966) (criminally committed persons).

According to Morton Birnbaum, who is usually considered the "father" of the right to treatment- see Birnbaum, The Right to Treatment, 46 A.B.A.J. 499 (1960)-a "number of distinguished judges . . . have avoided facing the complex problems" posed by the right to treatment concept. Birnbaum, Some Remarks on the "Right to Treatment," 23 ALA. L. REV. 623, 635 n.26 (1971).

29. The Court also noted that $O^{\prime} C o n n o r$ did not raise the issue of what may justify commitment in the first instance. 422 U.S. at 567.

30. Id. at 578 n.12. The Court's explicit mention of the effect of its vacating the judgment of the court of appeals was somewhat gratuitous because of the well-established effect of such a holding. The Court obviously recognized this because of its citation to United States v. Munsingwear, 340 U.S. 36 (1950). See also 422 U.S. at 580 (Burger, C.J., concurring): "The Court's opinion plainly gives no approval to that holding [of the court of appeals] and makes clear that it binds neither the parties to this case nor the Courts of the Fifth Circuit . . . . Moreover, in light of its importance for future litigation in this area, it should be emphasized that the Court of Appeals' analysis has no basis in the decisions of this Court."

31. Pennhurst State School \& Hosp. v. Halderman, 451 U.S. 1 n.12 (1981). A few lower federal and state courts have found a federal constitutional right to treatment, and others have done the same on the basis of state statutes.

In recent years the Third Circuit has replaced the Fifth Circuit as the front runner in right-to-treatment cases. Set Romeo v. Youngberg, 644 F.2d 147 (3d Cir. 1980); Scott v. Plante, 641 F.2d 117 (3d Cir. 1981), in addition to Halderman, supro.

Whether or not any state court has found a state constitutional right to treatment is not clear. According to one New Jersey Superior Court judge, "[w]hile not expressly holding, our Supreme Court has recognized the existence of a constitutional right to treatment. State v. Carter, 64 N.J. 382 (1974); State v. Krol, 68 N.J. 236 (1975); State v. Fields, 77 N.J. 282 (1978)." Patients, C.T. v. Camden County Bd. of Chosen Freeholders, No. L-33417-74 P.W. (N.J. Super. Ct. Law Div. Jan. 19, 1981). However, none of the cited cases state explicitly whether the basis for the right to treatment is statutory or constitutional, state or federal. See also In re Lavette M. v. Corporation Counsel, 35 N.Y.2d 136, 316 N.E.2d 327, 359 N.Y.S.2d (1974); People ex rel. Hutchings v. Smith, 50 A.D. 2d 1097, 377 N.Y.S.2d 366 (1975).

32. The separate concurring opinion of the Chief Justice, which may have originally been intended to be the opinion of the Court, see B. WoOdWARd \& S. ARMSTrong, The Brethren $381-82$ (1979), is 
case on the narrower issue of the "right to liberty."

For a few years, the Court's docket was relatively clear of mental health cases. ${ }^{33}$ However, in 1979, two significant cases were decided, Addington v. Texas ${ }^{34}$ and Parham v.J.R. ${ }^{35}$ Addington raised the question of what standard of proof is constitutionally required in civil commitment cases, an issue raised by another Texas case in which the Court had denied certiorari the previous term. ${ }^{36}$ Since the standard of proof was not prescribed by statute, the trial court applied a "clear, unequivocal and convincing evidence" standard, ${ }^{37}$ which the jury found to have been met. On appeal, the court of civil appeals reversed, holding that a "beyond a reasonable doubt" standard was required, citing only a decision by another division of that court. ${ }^{38}$ The Texas Supreme Court reversed, applying a "preponderance of the evidence" standard on the ground that Texas recognized only two standardsbeyond a reasonable doubt and preponderance of the evidence-but reinstated the trial court's judgment, though it was based on a higher standard, concluding that the error was harmless. ${ }^{39}$ Although each of the three Texas courts concluded that a different standard of proof should apply, the Supreme Court rejected all of them and settled on yet a fourth: "clear and convincing evidence." 40

especially hostile to the idea of a constitutional right to treatment, not only in the language emphasizing the Court's statement in footnote 12 that the Fifth Circuit's opinion is of no precedential value, see supra note 30, but throughout the opinion. See, e.g., 422 U.S. at 582 ("the idea that States may not confine the mentally ill except for the purpose of providing them with treatment is of very recent origin, and there is no historical basis for imposing such a limitation on state power"); id. at 587 ("[A] more troublesome feature of the [Fifth Circuit's] quid pro quo theory [of a right to treatment] is that it elevates a concern for essentially procedural safeguards into a new substantive consistutional right"); id. at 588-89 ("few things would be more fraught with peril than to irrevocably condition a State's power to protect the mentally ill upon the providing of 'such treatment as will give [them] a realistic opportunity to be cured' ").

33. There were, of course, a few denials of certiorari and dismissals of appeals. See, e.g., Winters v. Miller, 434 U.S. 968 (1977) (religious objections to psychiatric medications); Jones v. Florida, 430 U.S. 972 (1977) (right to jury trial in civil commitment proceedings); Vitello v. New York, 429 U.S. 1056 (1977) (right to treatment); In re Connors, 429 U.S. 999 (1976) (commitment standards for persons acquitted by reason of insanity); Folliard v. Semler, 429 U.S. 827 (1976) (tort liability of psychiatrist and hospital); In re Robb, 429 U.S. 802 (1976) (liability for cost of care provided criminally insane); Ziviak v. United States, 429 U.S. 801 (1976) (veterans benefits for parents of deceased incompetent veteran); McAuliffe v. Carlson, 427 U.S. 911 (1976); Farnum v. Committee on Character, 426 U.S. 943 (1976) (attorney required to submit to psychiatric examination as condition to admission to bar).

One of these cases, Turner v. Texas, 434 U.S. 929 (1978), in which certiorari was denied, raised precisely the same issue which the Court later decided in Addington v. Texas. See infra text accompanying notes $36-43$.

34. 441 U.S. 418 (1979).

35. 442 U.S. 584 (1979).

36. Turner v. Texas, 434 U.S. 929 (1978).

37. State v. Addington, 588 S.W.2d 569 (Tex. 1979).

38. Addington v. State, 546 S.W.2d 105 (Tex. Civ. App. Beaumont Div. 1977) (relying on Turner v. State, 543 S.W.2d 453 (Tex. Civ. App. Austin Div. 1976)).

39. State v. Addington, 557 S.W.2d 511 (Tex. 1977).

40. The Court rejected lower standards of proof (e.g., preponderance of the evidence) on the ground that they would unduly jeopardize individual liberty, and rejected higher standards of proof (e.g., beyond a reasonable doubt) on the ground that they would unduly frustrate legitimate state interests served by civil commitment. The Court also rejected the standard which the trial court had applied, the "clear, unequivocal and convincing" standard, as being too demanding since "[t]he term 'unequivocal,' taken by itself, means proof that admits of no doubt, a burden approximating, if not exceeding, that used in criminal cases." 441 U.S. at 432 . The Court distinguished deportation and denaturalization cases in which it had previously approved this standard as involving "issues [which] . . . were basically factual and therefore susceptible of objective proof and the consequences to the individual were unusually drastic . . . ." 
Even though a higher standard of proof than that adopted by the Court might thwart the state's legitimate interests, the Court left no doubt that the states are not constitutionally foreclosed from adopting a higher standard of proof if they wish, as some states have done either by statute or judicial decision. ${ }^{41}$ In other words, the Court's standard is only a "constitutional minimum,"42 and the states may adopt a higher standard of proof, either by statute or by case law drawing on the state constitution. ${ }^{43}$

Addington is a bit different from the other two constitutional cases in one particular. In the other cases, the Court was unwilling to go as far as the lower courts in protecting or creating rights of the mentally ill. In Addington, by contrast, the Court went further than the Supreme Court of Texas in protecting the rights of the mentally ill by requiring that a more stringent standard of proof be applied in civil commitment proceedings. However, by refusing to require the application of a reasonable doubt standard the Court did not go either as far as petitioners had sought or as far as some other lower courts had required.

Parham ${ }^{44}$ presents a stark contrast to Addington. The Court unequivocally cut back on a trend that had been developing rather clearly in the lower federal and state courts. The issues raised by the Parham case had been percolating in the lower courts, ${ }^{45}$ and indeed in the Supreme Court, ${ }^{46}$ for several years. Along with a companion case, Secretary of Public Welfare $v$. Institutionalized Juveniles, ${ }^{47}$ Parham raised the question of the extent of parental authority to admit a child to a psychiatric

Id. The Court also distinguished the holding in In re Winship, 397 U.S. 358 (1970), which applied the reasonable doubt standard in juvenile delinquency adjudications, by pointing to a variety of considerations in civil commitment cases that make that high standard inappropriate. 441 U.S. at 428-29.

41. In Addington, the Court mentioned 12 states which had adopted a criminal law standard of proof for civil commitment cases. 441 U.S. at 431 n.5.

Of course, those federal courts which had required a higher standard of proof on the basis of the Federal Constitution would seem to have been in error. See, e.g., Lessard v. Schmidt, 349 F. Supp. 1078 (E.D. Wis. 1972) (three-judge court), vacated and remanded on other grounds, 414 U.S. 473 (1974); In re Ballay, 482 F.2d 648 (D.C. Cir. 1973); Davis v. Watkins, 384 F. Supp. 1196 (N.D. Ohio 1974); In re Hodges, 325 A.2d 605 (D.C. App. 1974).

42. 441 U.S. at 431.

43. There does not appear to be any state constitutional provision which, by its terms, establishes a standard of proof. However, a few do create a presumption of innocence in criminal cases.

44. Parham v. J.R., 442 U.S. 584 (1979).

45. Parham itself was fled in October 1975, and was decided four months later. J.L. v. Parham, 412 F. Supp. 112 (M.D. Ga. 1976) (three-judge court). Prior to the filing of the complaint, the same or a similar issue had been litigated in other courts. See Bartley v. Kremans, 402 F. Supp. 1039 (E.D. Pa. 1975); Saville v. Treadway, 404 F. Supp. 430 (M.D. Tenn. 1974); Melville v. Sabbatino, 30 Conn. Supp. 320,313 A.2d 886 (Conn. Super. Ct. 1973). See generally Ellis, Voluntecring Children: Parental Commitment of Minors to Mental Institutions, 62 CAL. L. REv. 840, 849 (1974).

46. Bartley v. Kremens, 402 F. Supp. 1039 (E.D. Pa. 1975), raising essentially the same issue as Parham, was argued before the Supreme Court in December 1976. Kremens v. Bartley, 45 U.S.L.W. 3412 (U.S. 1976). The Court vacated and remanded on the ground that the case was moot as to the named plaintiff. 431 U.S. 119 (1977). It was about this time that the Court noted probable jurisdiction in Parham. Parham v. J.L., 431 U.S. 936 (1977). Parham was originally argued in December 1977, 46 U.S.L.W. 3386 (U.S. 1977), but was restored to the calendar for reargument during the 1978 Term. Parham v. J.L., 434 U.S. 1031 (1978). In the meantime, on remand, Bartley was redecided by the district court, in essentially the same manner as it had been originally. See Institutionalized Juveniles v. Secretary of Pub. Welfare, 459 F. Supp. 30 (E.D. Pa. 1978). The cases were consolidated for argument, which took place in October 1978, 47 U.S.L.W. 3263 (U.S. 1978), and the decisions were handed down together eight months later.

47. 442 U.S. 640 (1979). 
hospital. Georgia statutes authorized the psychiatric hospitalization of a child on the application of the child's parent or guardian to the regional hospital superintendent, who through a delegate would approve the application if the child were found to be mentally ill and treatable. Since discharge could be obtained by request of the parent or by request of the child after the child had reached the age of eighteen, the trial court concluded that "[c]hildren thus in practice have a right to leave only when the hospital and their parent or guardian agree."48 Relying on In re Gault, the trial court concluded that whatever else psychiatric hospitalization of children might entail, it also constituted a deprivation of liberty, and that the admission and discharge procedure denied the plaintiff-children due process. ${ }^{49}$

The Supreme Court was far less sympathetic to the plaintiffs' claims than the district court had been. In reversing the holding below, the Court characterized the district court's analysis as 'reject[ing] the State's entire system of providing mental health care . . . ."50 Employing an analysis similar to that used in Addington only two months earlier,51 the Court "balanced" factors to determine whether there had been a constitutional violation. Probably the decisive ingredient in the Court's analysis was its willingness, in contrast to the district court, to indulge a strong presumption that parents will act in their child's best interest. Thus, in accommodating the competing interests, the Court had little difficulty in rejecting the need for a judicial review of parental hospitalization decisions. Realizing, however, that there was still some risk of error in such decisions, the Court concluded that a "neutral factfinder" was required, but that a physician could adequately serve this function. ${ }^{52}$

The most striking conclusion arising from the three civil mental health cases in which the Supreme Court has engaged in plenary review is that the Court cannot be relied upon to break new constitutional ground in securing rights to psychiatric patients on the civil side of the mental health system. Nor can it be expected to uphold such action of the lower federal and state courts. The four "statutory" cases give no additional cause for optimism. ${ }^{53}$ Whether the Supreme Court has a particular aversion to mental patients, ${ }^{54}$ a cautious judicial philosophy in general,

48. J.L. v. Parham, 412 F. Supp. 112, 136 (M.D. Ga. 1976).

49. Id. at 136-37. In contrast to Bartley, the court did not prescribe acceptable commitment procedures. In Bartley, children were barred from being admitted to psychiatric hospitals, except on an emergency basis for a 72-hour period, without first having had an adversary judicial hearing. Bartley v. Kremens, 402 F. Supp. 1039 (E.D. Pa. 1975). Of the four significant cases dealing with the admission of children to psychiatric hospitals-Parham, Bartley, Saville v. Treadway, 404 F. Supp. 430 (M.D. Tenn. 1974), and In re Roger S., 19 Cal. 3d 921, 569 P.2d 1286, 141 Cal. Rptr. 298 (1977)-only Parham did not prescribe detailed procedures and procedural safeguards such as notice, hearings, and counsel.

50. 442 U.S. at 596.

51. This analysis is based on Mathews v. Eldridge, 424 U.S. 319, 335 (1976), and Smith v. Organization of Foster Families for Equality and Reform, 431 U.S. 816, 847-48 (1977).

52. 442 U.S. at 606-07. In another part of the opinion dealing with the hospitalization of children who were wards of the state, the Court also placed heavy weight on a presumption, which it found to arise from Georgia statutory obligation, that the child's guardian would act in the child's best interests, and that therefore there was no need for judicial review of hospitalization decisions when made by the guardian any more than when made by the parent. Id. at 617-18.

53. See supra note 6 .

54. Chief Justice Burger is reported to have referred to mental patients as " "those nuts." B. WOODWARd \& S. ARMSTrong, The Brethren 369 (1979). 
or an unwillingness to decide broad issues when narrower grounds for decision exist (as was the case in $O^{\prime}$ Connor), ${ }^{55}$ is not particularly significant for present purposes. What must be reiterated at the risk of overemphasis is that litigators acting on behalf of civilly committed mental patients must begin to look away from federal law (constitutional or statutory) for the source of rights that they seek to establish for their clients. To be ultimately successful, these litigators must look to places which can be shaded from review by the Supreme Court.

The only relatively reliable sanctuary from Supreme Court review lies in the state courts' ability to decide cases exclusively on the basis of state law: constitutional, statutory, common, or regulatory. Of course, this tactic will work only if the state-conferred rights exceed those required by the federal constitution. In the "independent and adequate state grounds" doctrine, mental health litigants can find such a sanctuary.

\section{II}

\section{The Independent And Adequate State Grounds DOctrine}

The history of state constitutions as a bulwark of individual liberties has been a cyclical one. Prior to the adoption of the 14th amendment, little protection was afforded individual rights under the Federal Constitution, leaving state constitutions as the primary source of protection for individual rights. The 14 th amendment, however, provided a convenient means for the assertion of federal authority in this area at a time when state protection was clearly inadequate. Thus, "the Supreme Court got into the business of developing the federal bill of rights,"56 interposing its protections not only between the citizen and the Federal Government but also between the citizen and state government. Consequentiy the importance of state constitutions in the protection of individual rights gradually diminished. The peak of federal protection of individual rights was reached under the guidance of Chief Justice Warren, especially in the criminal sphere. As the protection developed in the Warren Court has begun to wane in the Burger Court, state constitutional protections have begun to assume a new importance.

With the renewed interest in state constitutions, the doctrine of "independent and adequate state grounds" again has become a topic of interest and adjudication. It has been settled law since at least the middle of the last century that where a state court decision rests upon "independent and adequate state grounds," the Supreme Court will not upset that decision no matter how unwise it may think it to be; indeed, it will not even review the decision except to ascertain that it is supported by an independent and adequate state ground. ${ }^{57}$

55. The use of this particular reason for avoiding a broad ruling, along with the various doctrines for avoiding any decision such as mootness, standing, and justiciability, and, various procedural means for avoiding decision, is not peculiar to mental health litigation. These doctrines may always be invoked for reasons other than technical and narrow ones-that is, a justice or a court may genuinely believe that courts ought not to rule in such cases, or these doctrines and devices may be invoked to avoid ruling on substantive grounds for reasons which the justices do not wish formally to announce.

56. Countryman, Why a State Bill of Rights?, 45 WASH. L. REV. 454, 464 (1970).

57. There are actually two branches to the doctrine, one dealing with state procedural law and one with state substantive law. "State substantive grounds are honored unless they are 'patently evasive of or 
Essentially, the doctrine is a jurisdictional limitation. Although article III of the Constitution establishes the boundaries of the Court's jurisdiction, it does not expressly limit its appellate jurisdiction, a matter which is left to Congress. ${ }^{58}$ Since the enactment of the Judiciary Act of 1789, the Court's jurisdiction has changed very little. The current jurisdictional statute empowers the Court to review the final judgments of state courts only when a matter of federal law is involved. ${ }^{59}$ In practice, however, many cases present issues of both federal and state law, thus requiring the Court at least to inquire whether the decision is based on federal law or on a state ground. While viewed only as a matter of statutory interpretation at first, the doctrine is thought by some to have been elevated by Herb v. Pitcairm ${ }^{60}$ to one of constitutional dimension. ${ }^{61}$

The doctrine has enjoyed new vitality because of the unwillingness of some state supreme courts to accept the diminished protections accorded individual rights by the Burger Court. ${ }^{62}$ The doctrine has been invoked in a variety of substantive areas-among them economic regulation, church and state relations, environmental regulation, educational financing, and privacy ${ }^{63}$ _but nowhere with the vigor in cases involving the criminally accused. Two of these cases, State $v$.

discriminatory against federal rights.' State procedural grounds, on the other hand, may be disregarded simply 'because they [make] burdensome the vindication of federal rights.' " $16 \mathrm{C}$. WRIGHT, A. MILLER, E. Cooper, \& E. Gressman, Federal Practice And Procedure: Jurisdiction $§ 4020$, at 669 (1977) (quoting Fay v. Noia, 372 U.S. 391, 432 (1963)).

The difference between the substantive and procedural strains of the doctrine is that in the substantive area, the state court actually reaches the substantive claim, albeit at times on both state and federal grounds. In the procedural sphere, the state court decides the case on the basis of a state procedural rule, which decision precludes reaching the substantive merits of the claim. While state procedures must ordinarily be complied with when raising federal questions in state courts, the Supreme Court will not completely defer to these state requirements where honoring them would "endanger vindication of federal rights." G. Gunther, Cases and Materials on Constitutional Law 68 (9th ed. 1975).

58. "[T]he Supreme Court shall have appellate Jurisdiction . . . with such exceptions, and under such regulations as Congress shall make." U.S. CONST. art. III, $\S 2$.

59. 28 U.S.C. $\$ 1257$ (1976).

60. 324 U.S. 117 (1945).

61. See, e.g., Note, The Untenable Nonfederal Ground in the Supreme Court, 74 HARv. L. REV. 1375, 1378 (1961) ("an attempt has been made to raise the rule to constitutional dimensions"); see also Galie \& Galie, State Constitutional Guarantees and Supreme Court Review: Justice Marshall's Proposal in Oregon v. Hass, 82 Dick. L. REv. 273, 281 (1978). Even the Court does not seem sure whether the doctrine is constitutionally compelled. See Fay v. Noia, 372 U.S. 391,430 n.40 (1963). While Congress could extend the Court's jurisdiction so that the Court could review the state law questions presented in state cases involving both federal and state law questions, this seems unlikely in light of the length of time that the jurisdictional statutes have remained unchanged. If, however, Congress did choose to enlarge the Court's jurisdiction in this manner through reliance on the supremacy clause, the Court could hold such an extension unconstitutional on the basis of the 10th amendment. L. Tribe, American Constitutional LaW 120 (1978).

62. Since the early 1970's there have been recurrent predictions that the Burger Court would overturn many of the landmark criminal procedure rulings of the Warren Court. Although on balance most of these predictions have not materialized, there have been more than a handful of decisions in which the Court has limited the holdings of some of the earlier cases and refused to extend them in closely related cases. In some of these cases, the dissenters_key among them Justices Brennan and Marshall_have invited the state courts to redecide those cases on remand on the basis of state constitutional provisions. This is, of course, only possible where the case has come to the Court from a state court. Those cases involving federal crimes and actions for collateral relief brought against state authorities in the federal courts are not amenable to this procedure.

63. These are the categories which Professor Howard has developed, though I have changed the labels somewhat. See Howard, State Courts and Constitutional Rights in the Day of the Burger Court, 62 VA. L. REV. 873 (1976). 
Opperman ${ }^{64}$ and Commonwealth v. Campana, ${ }^{65}$ nicely illustrate how the doctrine operates, and suggest some of the potential pitfalls for the unwary litigant.

Opperman raised the question of whether an inventory of an automobile conducted by the police is a "search" which implicates fourth amendment protections. The South Dakota Supreme Court held that the inventory procedure was a search, that it was unreasonable because it was conducted without a warrant supported by probable cause and thus in violation of the fourth amendment, and ordered reversal of the conviction. On review, the U.S. Supreme Court held that the conviction must be reinstated, reasoning that "the inherent mobility of automobiles creates circumstances of such exigency that, as a practical necessity, rigorous enforcement of the warrant requirement is impossible,"66 and thus the warrantless "inventory" was not unreasonable and therefore not in violation of the fourth amendment.

Justice Marshall, in a dissent joined by Justices Brennan and Stewart, explained the basis for his disagreement with the majority's reasoning, and concluded his opinion with a thinly veiled invitation to the South Dakota Supreme Court to circumvent the Court's holding on state constitutional grounds:

On remand it should be clear in any event that this Court's holding does not preclude a contrary resolution of this case or others involving the same issues under any applicable state law. See Oregon v. Hass, 420 U.S. 714, 726 (1975) (Marshall, J., dissenting). ${ }^{67}$

The reference to Oregon $v$. Hass may seem like merely another illustration of the common judicial practice of providing a citation to a precedent. But behind this cryptic reference is the independent and adequate state grounds doctrine, the application of which Justice Marshall had defended in Oregon $v$. Hass against the majority's holding that it was inapplicable, by explicating Justice Jackson's famous opinion in Herb v. Pitcaim.68

The reference was anything but cryptic to the South Dakota Supreme Court. On remand, it held "that the inventory procedure followed in this instance constitutes an unreasonable search under our state constitution . . . ."69 The applicable provision of the South Dakota constitution ${ }^{70}$ is not only modeled on the fourth amendment, but is a verbatim transcription of it with only minor stylistic changes such as "warrant" instead of "Warrants" and "affidavit" instead of "Oath or affirmation." The result could not be more striking unless those stylistic differences had been cited as the reason for the differing holdings. 'The state court acknowledged that the two provisions were almost identical, and correctly justified its holding by explaining that since " $[\mathrm{t}]$ his court is the final authority on interpretation and enforcement of the South Dakota constitution . . . we have the right to

64. 228 N.W.2d 152 (S.D. 1975), rev'd and remanded, 428 U.S. 364 (1976), on remand, 247 N.W.2d 673 (S.D. 1976).

65. 452 Pa. 233, 304 A.2d 432, vacated and remanded, 414 U.S. 808 (1973), on remand, 455 Pa. 622, 314 A.2d 854, cert. denied, 417 U.S. 969 (1974).

66. South Dakota v. Opperman, 428 U.S. 364, 367 (1976).

67. Id. at 396 .

68. See supra text accompanying notes 56-59.

69. State v. Opperman, 247 N.W.2d 673, 674 (S.D. 1976).

70. S.D. ConsT. art. VI, $\$ 11$. 
construe our state constitutional provision in accordance with what we conceive to be its plain meaning." 71 As if to emphasize that it was not to be outdone by the Supreme Court, the court rejected the state's argument that the petitioner had abandoned his right to raise the state constitutional ground originally raised at the suppression hearing, but not briefed or argued on the first appeal, since the parties had adequate notice to brief and argue the point on remand. Knowing that it was beaten, the state did not apply for certiorari after the decision on remand.

Campana, in some respects, provides an even more graphic illustration of how the independent and adequate state grounds doctrine operates. The state there did petition for certiorari after the decision on remand, and the petition was denied. This case presented a double jeopardy issue, and the Pennsylvania Supreme Court held that the defendant had been subjected to double jeopardy "in contravention of the Fifth and Fourteenth Amendments of the United States Constitution."72 However, juxtaposed with its discussion of the fifth amendment double jeopardy clause was a discussion of the double jeopardy clause of the Pennsylvania constitution, which the court noted differed "only stylistically from that contained in the Fifth Amendment . . . ."73 The state's petition for certiorari was granted and simultaneously the judgment was vacated and the case remanded for the Pennsylvania court "to consider whether [the] judgment [is] based on federal or state constitutional grounds, or both."74 The import of that terse order was clear, and not surprisingly on remand the Pennsylvania court held that its earlier decision was based on state law, albeit the court's supervisory powers rather than the state constitution. ${ }^{75}$

The Opperman and Campana cases are two of the many examples ${ }^{76}$ of actions by state supreme courts to shield their holdings from Supreme Court review and possible reversal or, where the Court has already expressed its view of the merits under the Federal Constitution - as in Opperman-effectively to overrule the Court. In some cases-Campana is one-the state court decides the issue on ambiguous grounds, creating a situation in which the Court must remand for a clarification of

71. 247 N.W.2d at $674-75$.

72. Commonwealth v. Campana, 452 Pa. 233, 239-40, 304 A.2d 432, 434 (1973).

73. $452 \mathrm{~Pa}$. at $243,304 \mathrm{~A} .2 \mathrm{~d}$ at 436 . The textual differences between the Pennsylvania and federal double jeopardy clauses are more substantial than the differences between the South Dakota and federal search and seizure prohibitions at issue in Opperman, but they are equally inconsequential in meaning.

74. Pennsylvania v. Campana, 414 U.S. 808, 808 (1973).

75. Commonwealth v. Campana, $455 \mathrm{~Pa} .622,624,314$ A.2d 854, 855 (1974). In its original disposition of the case, the majority of the Pennsylvania Supreme Court could not agree on the basis for the judgment, and hence there were three separate opinions in support of the judgment, and the opinion on remand admits that "[t]here are, of course, indications in some of the opinions supporting our judgments that a basis for the judgments was to be found in federal constitutional problems [sic]." Id. Nonetheless, the court summarily concluded that "there are also separate reason [sic] advanced for the result that do not stand on a view of federal constitutional requirements," id., and went on to characterize them as the "broad" supervisory power over state criminal proceedings. There is more than just a bit of sophistry, or at least post facto rationalization, in this opinion.

76. See Brennan, State Constitutions and the Protection of Individual Rights, 90 HARV. L. REV. 489 (1977); Galie, State Constitutional Guarantees and Protection of Defendant's Rights: The Case of New York, 1960-1978, 28 BuFf. L. REV. 157 (1979); Wilkes, The New Federalism in Criminal Procedure: State Court Evasion of the Burger Court, 62 KY. L.J. 421 (1973-74); Comment, Anderson and the Adequate State Ground, 45 S. CAL. L. REv. 750 (1972); Note, Slate Constitutional Guarantees as Adequate State Ground: Supreme Court Review and Problems of Federalism, 13 AM. CRIM. L. REV. 737 (1976). 
the grounds; in other cases, of which Opperman is an example, the state court clearly decides the issue on federal grounds in the first instance, but on remand decides the case on state grounds. The third and most obvious way in which a state court can shield its holdings not only from reversal, but probably even from review, is by clearly deciding the case on state law grounds in the first instance.

There is no reason why state law grounds for decision-and of course, constitutions are only one such basis cannot be employed in mental health cases. In fact, a few cases have already been decided on state constitutional grounds though it appears that only one used the independent and adequate state grounds doctrine to insulate the state court holding from Supreme Court reversal. That case was Department of Mental Hygiene v. Kirchner, ${ }^{77}$ decided in the early 1960's, in which the California Supreme Court held that a state statute, which required certain relatives of a person hospitalized for mental illness to reimburse the state for the cost of the care, violated "equal protection."78 Because the opinion was ambiguous as to the ground relied upon, the Court refused to "speculate from the choice of words used in the opinion, and the authorities cited by the court, which provision was the basis for the judgment . . ."79 and remanded for clarification. On remand, the California Supreme Court, in a per curiam opinion, not surprisingly held that while the state and federal equal protection provisions are normally treated as "substantially . . . equivalent," 80 in this case the decision was based on the state clause.

Had the same issues presented in Addington arisen in a slightly different fashion, the way in which a state constitutional provision-or indeed any other independent and adequate state ground-might have come into play is easy to see. $^{81}$ First, the Texas Supreme Court would have had to have held on the basis of

77. 29 Cal. Rptr. 312 (Cal. App. 1963), vacated and remanded, 60 Cal. 2d 716, 388 P.2d 720 , 36 Cal. Rptr. 488 (1964), vacated and remanded, 380 U.S. 194 (1965), on remand, 62 Cal. 2d 586, 400 P.2d 321,43 Cal. Rptr. 329, (1965).

78. The court specified neither the California nor the Federal Constitution when referring to "equal protection" but it did cite two California cases dealing with equal protection. Neither of these cases, Blumenthal v. Board of Medical Examiners, 57 Cal. 2d 228, 368 P.2d 101, 18 Cal. Rptr. 501, (1962); Bilyeu v. State Employees' Retirement Sys., 58 Cal. 2d 618, 375 P.2d 442, 25 Cal. Rptr. 562, (1962), indicates whether the court was relying upon the federal or state equal protection clauses.

79. 380 U.S. at 196.

80. 62 Cal. $2 d$ at 588,400 P.2d at 322,43 Cal. Rptr. at 330.

81. It is not possible to apply the independent and adequate state grounds approach where the case is first brought in federal court exclusively on federal law theories, as was the case in Donaldson and Parham. However, where the action is brought in federal court under federal question jurisdiction and there are pendent state law claims, on remand from the Supreme Court to a federal court of appeals and then to a district court, the district court has broad discretion to rule on or to dismiss pendent state law claims which have not yet been adjudicated. See generally $13 \mathrm{C}$. Wright, A. Miller \& E. CoOper, Federal Practice \& Procedure $\$ 3567$, at 448-55 (1975) [hereinafter cited as Wright, MILler \& CoOPER]. An example of this in the mental health law context is the Pennhurst case, originally brought in federal district court on federal constitutional and statutory, and state statutory theories. Halderman v. Pennhurst State School \& Hosp., 446 F. Supp. 1295 (E.D. Pa. 1977). On appeal, the judgment was modified and affirmed on federal statutory grounds alone. Halderman v. Pennhurst State School \& Hosp., 612 F.2d 84 (3d Cir. 1979). The Supreme Court reversed and remanded, 451 U.S. 1 (1981), and the court of appeals then reinstated the judgment on state statutory grounds. In its opinion, the court of appeals noted that

the Supreme Court has expressed no view on the question whether state law provides an independent and adequate ground which can support the district court order. We are directed to consider that question in light of [a] decision . . . announced by the Pennsylvania Supreme Court after our decision 
the Federal Constitution, contrary to its actual holding, that a "reasonable doubt" standard of proof should be applied. The state would then have sought review in the Supreme Court, contending that this standard of proof was not constitutionally mandated. The Court then would have held as it did: that the Constitution requires in civil commitment cases no more than proof by clear and convincing evidence, and it would have reversed and remanded to the Texas Supreme Court for further proceedings. The Texas court could than have redecided the case on the basis of Texas law, holding that Texas constitutional or common law requires proof beyond a reasonable doubt. ${ }^{82}$ Had the state wished to challenge this holding, its only avenue for review would have been to the United States Supreme Court, which ought to deny review on the basis of the independent and adequate state grounds doctrine. Such a procedure, analogous to what has been happening in criminal procedure issues before the Supreme Court for several years, does have certain pitfalls. ${ }^{83}$

One potential obstacle, which arose in Opperman, is waiver or abandonment. Litigants who fail to raise state law claims at the outset, or who having raised them initially abandon them at some later point in the proceedings, run the risk that the state court will refuse to reach the merits of the claim on state law grounds. It is unlikely, as Opperman illustrates, that a state court that wishes to avoid a Supreme Court reversal will be put off by an argument of waiver or abandonment. Rather, in the interest of fairness, it might instead provide the opposing party with a time extension to brief and argue the issue on the state law ground.

Another problem in this area-not so much an obstacle as an inconvenienceis the failure of the state courts to clarify their grounds of decision. When this occurs, it means that the Court must first grant certiorari, then review the case, then remand for clarification. If the state court then holds that its former decision was based on state grounds, there either will be no second petition for certiorari, or it will most certainly be denied. In contrast, if the state court had clearly signified state law as the ground of decision in the first instance, the petition for certiorari could probably have been avoided. There is also the possibility that a state supreme court, having first held that the Federal Constitution secures certain rights, may change its position on remand after hearing the Supreme Court's views on the matter and would thus be unwilling to rule similarly even on state law grounds. Had the original claim been made on state law grounds, the state court might have ruled favorably to the claimant. In order to avoid these potential pitfalls, litigants should clarify in their pleadings, briefs, and arguments both the federal and state laws-constitutions, statutes, cases, regulations-on which they are

but prior to that of the Supreme Court. Implicit in that direction is a holding that the plaintiffs' federal law claims are of sufficient substance to support the exercise of pendent jurisdiction over that Pennsylvania law claim.

673 F.2d 647, 650 (3d Cir. 1982). The Supreme Court has again granted certioriari. 102 S. Ct. 2956 (1982).

82. See infra note 86 and accompanying text.

83. An additional pitfall is that the expansion of state constitutional rights may collide with the federal or state constitutional rights of other persons. See infra note 147. 
basing their claims for relief. Undoubtedly, litigants' ambiguity has often contributed to the ambiguity of courts in articulating the ground for decision.

The forum in which to raise state law claims must be chosen with caution. Where such claims are combined with claims based on federal law, they may be raised not only in state court but also in federal courts under pendent jurisdiction. If the federal trial and appellate courts hold favorably to the plaintiff on a federal ground and the Supreme Court reverses, it is not entirely clear that on remand the trial court can or will then decide the issue on a state law basis. Certainly, considerations of judicial economy argue in favor of the trial court's making a decision on the state law claim, especially where there has been extensive discovery and trial of the matter. ${ }^{84}$ However, since the trial court has discretion on whether or not to hear the state law claim, the plaintiff runs the risk of dismissal and relitigation of the claim in state court. This risk will be especially high where the state courts have not spoken on the question since the federal trial courts reluctantly adjudicate novel questions of state law. ${ }^{85}$ In addition, the claim may become barred in the state courts by the running of the statute of limitations.

III

\section{State Constitutions and Mental Health Litigation}

In what specific ways can state constitutions be utilized in mental health litigation? The obvious situations are presented in the three constitutional cases already decided by the Supreme Court. Circumvention of the Court's ruling in Addington provides the clearest and simplest illustration. Proponents of a standard of proof higher than clear and convincing evidence may find support in a state constitutional provision, as the New Hampshire Supreme Court has. ${ }^{86}$ Reliance on such a provision arguably should not even be characterized as a "circumvention" of the

84. See United Mine Workers v. Gibbs, 383 U.S. 715 (1966). Also, if the claim is barred in state court by the statute of limitations, the federal court ought to decide the state law question. Billington $v$. Hayduk, 439 F. Supp. 971 (S.D.N.Y. 1977); 17 WRIGHT, MILLER \& COOPER, supra note 79, § 4243, at 47475 (1978).

85. See 17 WRIGHT, Miller \& CoOPER, supra note 79, $\$ 4241$, at 433 (1978). However, abstention is not the only alternative. The federal court may also certify the question to the state courts. See generally C. Wright, LaW OF Federal Courts 225-27 (3d ed. 1976).

86. See Proctor v. Butler, 117 N.H. 927, 380 A.2d 673 (1977). This case not only illustrates how a state court may rely on its own constitution to establish protections which the Supreme Court is unwilling to find in the Federal Constitution-though admittedly this case was decided before the Court denied the protection in question-but how a court may be willing read expansively to the text of its own constitution. The New Hampshire constitution contains no express provision pertaining to the standard of proof which prompted the court to refer to part I, article 15 of the constitution as the basis for its holding. This clause states in relevant part that "[n]o subject . . . shall be . . . deprived of his life, liberty or estate, but by the judgment of his peers, or the law of the land." However, it is by its terms limited to "crime[s], or offense[s]" and thus the court was required to read the text broadly to apply it to civil commitment proceedings. See also infra note 107 .

The California Supreme Court has applied a reasonable doubt standard of proof in a variety of cases involving commitment to therapeutic settings, though none are garden variety civil commitments of mentally ill persons. See Estate of Roulet, 23 Cal. 3d 219, 590 P.2d 1, 152 Cal. Rptr. 425 (1979) (proceedings for the appointment of a conservator); People v. Thomas, 19 Cal. 3d 630, 566 P.2d 228, 139 Cal. Rptr. 594 (1977) (commitment of narcotics addict); People v. Burnick, 14 Cal. 3d 306, 535 P.2d 352, 121 Cal. Rptr. 488 (1975) (commitment of mentally disordered sex offender); People v. Feagley, 14 Cal. 3d 388, 535 P.2d 373, 121 Cal. Rptr. 509 (1975) (commitment as a mentally disordered sex offender). 
Addington holding because the Court specifically recognized that the standard adopted was a constitutional minimum.

The issue ruled upon in Parham is also relatively clear. In deciding a case on similar facts, a state court would be free, even if it employed the Court's Parham analysis, to strike a different balance among the competing interests, if the state court could be convinced that less weight should be accorded the presumption that parents act in the best interests of their children. The California Supreme Court did precisely this in In re Roger $S .{ }^{87}$ decided two years before Parham on the basis of both the federal and state due process clauses. ${ }^{88}$ On the issue of what process is due children who are wards of the state, a court in a state lacking a statutory provision like Georgia's, ${ }^{89}$ which the majority read as requiring state employees to "protect a child's general welfare,"90 might find more easily than did the Supreme Court that more stringent protections must be accorded children faced with psychiatric hospitalization. In this task they would find additional guidance in the dissenting opinion in Parham penned by Justice Brennan.

O'Connor, on the other hand, provides the basis for a somewhat cloudier illustration of how a state court might now proceed in a case raising the right-to-treatment issue. If the Court had held in O'Connor $v$. Donaldson that the Constitution does not secure a right to treatment, circumvention of this ruling on independent and adequate state grounds would be relatively simple under any one of a number of state constitutional bases. These bases include the due process and equal protection clauses and the prohibition on cruel and unusual punishment which have been suggested by commentators as supporting a right to treatment under the Federal Constitution. ${ }^{91}$ But this is not what the Court held. Indeed, the Court refused

87. 19 Cal. 3d 921, 569 P.2d 1286, 141 Cal. Rptr. 298 (1977).

88. Review by the United States Supreme Court was not sought in this case. If review had been sought and if the case had arisen post-Parham, the Court likely would have either reversed on the federal constitutional issue and remanded for a clarification by the state court as to whether the state constitution alone supported the holding, or have held that there was an independent and adequate state ground for the holding.

A due process or equal protection clause is the most likely means for obtaining a state-law ruling contrary to Parham. In at least one state, however, there may be another way. Montana's Declaration of Rights states that " $[t]$ he rights of persons under 18 years of age shall include, but not be limited to, all the fundamental rights of this Article unless specifically precluded by laws which enhance the protection of such persons." MONT. CONST. art. II, $\S 15$.

89. GA. CODE ANN. § 24A-101 (1981):

This Code [Title 24A] shall be liberally construed to the end that children whose well-being is threatened shall be assisted and protected and restored, if possible, as secure law-abiding members of society; and that each child coming within the jurisdiction of the court shall receive, preferably in his own home, the care, guidance, and control that will conduce to his welfare and the best interest of the State, and that when he is removed from the control of his parents the court shall secure for him care as nearly as possible equivalent to that which they should have given him.

90. 442 U.S. at 618.

91. A federal constitutional right to treatment has been posited on three grounds: due process, equal protection, and cruel and unusual punishment. See generally Developments in the Law-Civil Commitment of the Menially Ill, 87 HARV. L. REv. 1190, 1324-33 (1974) [hereinafter cited as Developments].

Several state constitutions contain provisions which might prove helpful in right-to-treatment litigation, though none explicitly establishes such a right. For instance, the Mississippi constitution provides that "[i]t shall be the duty of the legislature to provide by law for the treatment and care of the insane ....." Miss. Const. art. 4, § 86; accord IDAHO Const. art. X, § 1; MONT. Const. art. XII, § 3; OHIO Const. of 1851 , art. VII, $\S 1$; OKLA. Const. art. XXI, $\$ 1$; UTAH Const. art. XIX, $\S 2$; WaSH. Const. art. XIII, $\S 1$. Cf. ARK. Const. art. XIX, $\S 19 ;$ S.C. Const. art. XII, $\S 1$ (1895, amended 1971). Perhaps 
to reach the issue. Thus, there is no precedent barring a lower court, state or federal, from holding that there is a right to treatment based on the Federal Constitution. In fact, subsequent to the $O^{\prime}$ Connor decision, other courts have so held. ${ }^{92}$ The problem that the right-to-treatment issue poses is more amorphous than the "standard of proof" or "hospitalization of children" issues, where stare decisis precludes reliance on the Federal Constitution. In this situation it is the risk, rather than the near certainty of reversal, which is the impetus to reliance on state, rather than federal, constitutional grounds.

Besides the issues raised in the three constitutional cases, the cases in which the Court has summarily affirmed the adverse holdings of lower courts are especially ripe for litigation on state constitutional grounds as are cases in which the Court has denied certiorari. ${ }^{93}$ But these cases raise only a fraction of the potential issues in mental health litigation. The remainder of this section will describe and illustrate $e^{94}$ the other significant areas for which state constitutional grounds might pro-

the most explicit provisions are those in the Hawaii and Michigan constitutions providing that " $[t]$ he State shall have the power to provide for the treatment and rehabilitation of handicapped persons," HaWAlI CoNST. art. IX, $\S 2$, and "[i]nstitutions, programs and services for the care, treatment, education or rehabilitation of those inhabitants who are physically, mentally or otherwise seriously handicapped shall always be fostered and supported." MICH. CoNST, art. 8, § 8 . Some constitutions contain provisions like Idaho's, which might also assist in securing a right to treatment in the most appropriate (or least restrictive) setting: "[I]nstitutions . . . for the benefit of the insane. . . and such other institutions as the public good may require, shall be established and supported by this state . . . " IDAHO CONST. art. X, § 1 (emphasis added); accord WASH. CONST. art. XIII, $\S 1$. Where a court refuses to recognize a right to treatment, it may still be willing to acknowledge the state's duty to protect institutionalized persons from harm. See, e.g., New York Ass'n of Retarded Children v. Rockefeller, 357 F. Supp. 752 (E.D.N.Y. 1973). A provision of the Louisiana constitution which states that "[n]o law shall subject any person to euthanasia, to torture, or to cruel, excessive, or unusual punishment" might assist in establishing such a right. LA. ConsT. art. I, § 20. Every state constitution prohibits cruel and unusual punishment or its equivalent.

92. See, e.g., Bowring v. Godwin, 551 F.2d 44 (4th Cir. 1977) (mentally ill prisoners); Welsch v. Likins, 550 F.2d 1122 (8th Cir. 1977) (civilly committed mentally retarded persons); Scott v. Plante, 532 F.2d 939 (3d Cir. 1976) (mentally ill prisoners); Eckerhart v. Hensley, 475 F. Supp. 908 (W.D. Mo. 1979) (majority of plaintiffs had entered mental health system through criminal system); Davis v. Balson, 461 F. Supp. 842 (W.D. Ohio 1978) (criminally insane); Morgan v. Sproat, 432 F. Supp. 1130 (S.D. Miss. 1977) (incarcerated juveniles); Gary W. v. Louisiana, 437 F. Supp. 1209 (E.D. La. 1976) (civilly committed mentally retarded children).

In addition to these cases holding that there is a constitutional right to treatment, there are others which have reached the same result on the basis of state statutory provisions, see 3 MENT. DIS. L. RPTR. 357.59 (1979) (table of statutes), and several others have settled the issue by consent decree. See 4 MENT. Dis. L. RPTR. 44 (1979).

93. See supra notes 23-24.

94. It is an extremely time-consuming task to identify the civil mental health cases that have been decided on the basis of state constitutions. The West Digest system does not classify cases in this way, and indeed does not even provide a ready means for identifying civil and criminal mental health cases decided on the basis of state constitutions. It is also impossible to perform a Lexis search which accurately identifies such cases. Any such search will either be underinclusive as it runs the risk of excluding some cases if the instructions call for ignoring cases with the word "criminal" (or some variation) in them, or is extremely overinclusive when the search includes criminal cases. My Lexis search of California cases yielded between 150 and 200 cases since 1970 . The vast majority involved persons other than civilly committed mental patients, such as criminals (incompetent to stand trial, not guilty by reason of insanity and those committed to therapeutic settings in lieu of prison terms), drug addicts, juvenile delinquents, incompetent wards, and developmentally disabled or mentally retarded persons.

The same Lexis search used to retrieve the California cases was also run on the other 49 states, yielding another 1200 or so cases in which state constitutions were implicated in mental health litigation. Because of the large number of cases, I have not attempted to ascertain what proportion of them are "civil" mental health cases. Although the proportion of civil to criminal mental health cases in other jurisdictions might 
vide an alternative to the Federal Constitution.

There are three general areas in which safeguards of individual rights of persons in the civil mental health system may be necessary: (1) in the process of becoming a psychiatric patient, i.e., the civil commitment process; (2) in treatment settings; and (3) in discrimination by society as a result of past or present mental disability. These divisions are somewhat arbitrary, and the problems that arise in one context may well overlap with or duplicate problems arising in another context.

\section{The Civil Commitment Process}

There has been a substantial amount of litigation in the 1970's over both the substantive standards for involuntary psychiatric hospitalization and the procedural safeguards required in the commitment process. Even though the three cases decided by the Supreme Court touch on these aspects of mental health law-Addington and Parham are holdings on procedural points; $O$ 'Connor has implications for substantive commitment standards ${ }^{95}$ - there are a multitude of issues which the Court has not confronted. The litigation in the lower courts has proceeded almost entirely on the basis of the due process clause of the 14th amendment. This litigation has been so successful that the legislatures of most states have adopted substantive commitment criteria which comport with these judicial decisions, thus averting much potential litigation. ${ }^{96}$

The procedural requisites for constitutionally permissible commitments have also been the subject of much judicial, and subsequently legislative, scrutiny over the last decade. Issues involving the necessity for hearings, notice, counsel, presence of the patient at the hearing, examination and cross-examination of witnesses, "independent" expert witnesses for indigents, transcripts, and appeals have, along with other procedural issues, been thoroughly litigated in a large number of jurisdictions, usually favorably to patients. ${ }^{97}$

be expected to be roughly the same as in California, differences in the state constitutions might result in quite different proportions.

95. Despite the fact that the Court expressly disavowed any intention to rule on the legality of Donaldson's initial confinement, the implication of the holding that one must be released from a psychiatric hospital if one is not dangerous and can exist safely in the community is that one cannot be committed at the outset if one is not dangerous and can live safely in the community. Some courts have relied on O'Connor v. Donaldson for this proposition. See, e.g., Bethany v. Stubbs, 393 So. 2d 1351 (Miss. 1981); see also Rennie v. Klein, 653 F.2d 836, 845 (3d Cir. 1981).

96. There is, however, one issue of great significance in the area of commitment criteria which few, if any, courts have ruled upon: whether or not the Constitution requires that a person be proven incapable of making a rational decision about hospitalization to be committable under the parens patriae power of the state. See Developments, supra note 91 , at 1210-22. There are some important dicta in the right-to-refusetreatment cases, especially Rogers v. Okin, 634 F.2d 650 (1st Cir. 1980), bearing on this issue. The analagous issue in police power commitments is whether or not the individual sought to be committed must be shown to be incapable of controlling his "dangerous" behavior in order to be committed in accordance with constitutional requisites. See Developments, supra note 91, at 1223-45.

97. See, e.g., Suzuki v. Yuen, 617 F.2d 173 (9th Cir. 1980); In re Ballay, 482 F.2d 648 (D.C. Cir. 1973); Dorsey v. Solomon, 435 F. Supp. 725 (D. Md. 1977), affd in part and remanded, 604 F.2d 271 (4th Cir. 1979); Stamus v. Leonhardt, 414 F. Supp. 439 (S.D. Iowa 1976); Coll v. Hyland, 411 F. Supp. 905 (D.N.J. 1976) (three-judge court); Doremus v. Farrell, 407 F. Supp. 509 (D. Neb. 1975) (three-judge court); Kendall v. True, 391 F. Supp. 413 (W.D. Ky. 1975) (three-judge court); Lynch v. Baxley, 385 F. Supp. 378 (M.D. Ala. 1974) (three-judge court); Bell v. Wayne County Gen. Hosp., 384 F. Supp. 1085 (E.D. Mich. 1974) (three- 
There are some issues which have not been resolved to the satisfaction of patients' interests. And again, the legislatures have often acted either at the prodding of the courts or, conversely, to preempt judicial activity. Where such litigation has not occurred, there are good reasons to proceed on federal constitutional grounds since there are so many favorable rulings to cite from other jurisdictions, including decisions from the federal courts of appeal. The Supreme Court has ruled adversely on only two of these issues (and those were summary affirmances ${ }^{98}$ ), though there have been several denials of certiorari. ${ }^{99}$

There are two other procedural issues-the privilege against self-incrimination and the right to jury trial-which have received far less favorable treatment in the courts on the basis of the Federal Constitution. In addition, Supreme Court case law presages an ill reception should these issues reach the Court. Indeed, it is likely that the existence of this case law has been largely responsible for the lack of success on these issues in the lower courts.

Litigants involved in the civil side of the mental health process who have sought to have the privilege against self-incrimination applied to psychiatric interviews have generally been unsuccessful. ${ }^{100}$ Litigation has also occurred over whether patients have a right to be informed that they need not speak to a psychiatrist and a right to have counsel present during a psychiatric interview. ${ }^{101}$ On some aspects of this constellation of interrelated issues the courts have been more

judge court); Dixon v. Attorney Gen., 325 F. Supp. 966 (M.D. Pa. 1971) (three-judge court); Fhagen v. Miller, 317 N.Y.S.2d 128 (Sup. Ct. 1970), modified, 36 A.D.2d 926, 321 N.Y.S.2d 61 (1971), affd, 29 N.Y.2d 348, 278 N.E.2d 615, 328 N.Y.S.2d 393, cert. denied, 409 U.S. 845 (1972); Commonwealth ex rel. Finken v. Roop, 234 Pa. Super. 155, 339 A.2d 764 (1975), appeal dismissed, 424 U.S. 960 (1976); State ex rel. Hawks v. Lazaro, 202 S.E.2d 109 (W. Va. 1974).

The only state constitutional provision which, by its terms, pertains to the procedural rights of persons in the civil commitment process is TEX. CONST. art. I, $\$ 15-a$, which besides requiring that commitments be supported by "competent medical or psychiatric testimony," does little more than empower the legislature to enact statutes in this area.

98. See supra note 14 .

99. See supra notes 24-33.

100. The leading case to hold that the privilege against self-incrimination applies to psychiatric examinations (the case also held that the patient must be informed of his right to silence), is Suzuki v. Quisenberry, 411 F. Supp. 1113, 1131 (D. Hawaii 1976), which was reversed on appeal. Suzuki v. Yuen, 617 F.2d 173 (9th Cir. 1980). See also Lessard v. Schmidt, 349 F. Supp. 1078 (E.D. Wis. 1972). Most cases considering the issue have held the privilege inapplicable. See, e.g., French v. Blackburn, 428 F. Supp. 1351 (M.D.N.C. 1977), affd mem., 442 U.S. 901 (1979); People ex rel. Keith v. Keith, 38 Ill. 2d 405, 231 N.E.2d 387 (1967); State ex rel. Hawks v. Lazaro, 202 S.E.2d 109 (W. Va. 1974). See generally Fielding, Compulsory Psychiatric Examination in Civil Commitment and the Privilege Against Self-Incrimination, 9 GONZ. L. REV. 117 (1973); Wesson, The Privilege Against Self-Incrimination in Civil Commitment Proceedings, 1980 WIS. L. REV. 697; Preparation and Trial of a Civil Commitment Case, 5 Mental Disability L. ReP. 201, $207-08$ (1981).

It is fairly well settled that there is no constitutional privilege against self-incrimination in psychiatric examinations to determine competency to stand trial or criminal responsibility, at least not where the matter has been put in issue by the defendant. See generally Annot., 3 A.L.R.4TH 910 (1981). Cf. Annot., 32 A.L.R.2D 434 (1953) (statutory provisions). However, where a pre-trial psychiatric interview also touches on issues relevant to punishment, the privilege applies. Estelle v. Smith, 451 U.S. 454 (1981).

101. See Lessard v. Schmidt, 349 F. Supp. 1078 (E.D. Wis. 1972), holding that there is no right to have counsel present during a psychiatric interview performed to determine whether one is civilly commitable. Compare Annot., 3 A.L.R.4TH 910 (1981). Suzuki v. Quisenberry, 411 F. Supp. 1113, 1131 (D. Haw. 1976), held that not only is there a privilege against self-incrimination in a psychiatric interview for civil commitment but that the patient must be informed of his right to silence. These portions of the holding, however, were overturned on appeal. See Suzuki v. Yuen, 617 F.2d 173 (9th Cir. 1980). See generally Preparation and Trial of a Civil Commilment Case, 5 Mental Disability L. ReP. 201, 207 (1981). 
receptive than on others, but on balance there have been few inroads made by patients in this area. ${ }^{102}$

One of the few courts that has been somewhat receptive to the privilege, holding that it does apply in examinations by psychiatrists in connection with civil commitment proceedings, and citing Justice Douglas's concurring opinion in McNeil v. Director, Patuxent Institution, ${ }^{103} \mathrm{did}$, however, refuse to permit counsel to be present during the examination, offering the stock explanation that "the prospect of a seriously ill individual being prevented from obtaining needed treatment, in a situation in which treatment is possible and will actually be given, on the basis of counsel's advice to refuse to make any statements to a psychiatrist appears ludicrous." 104 While the presence of counsel may interfere with a psychiatric evaluation, thus undermining the state's interest in providing treatment, it is hardly likely that it undermines the state's legitimate interest-in this case, providing treatment-any more than the presence of counsel in a police interrogation impedes the state's interest in conviction. It is not merely the individual's interest in liberty that dictates the presence of counsel, but the state's interest in assuring the integrity of the police interrogation or the psychiatric evaluation. ${ }^{105}$

The constitutional sources for this constellation of rights have ordinarily been

102. In a closely related issue involving psychiatric patients on the criminal side of the mental health system, the Supreme Court declined to rule on whether or not a person convicted of a crime, whom the state seeks to subject to a psychiatric evaluation in order to determine whether he is a "defective delinquent," may invoke the privilege against self-incrimination. McNeil v. Director, Patuxent Inst., 407 U.S. 245 (1972). See supra note 20.

More recently, the Court ruled that one charged with a crime who is examined by a psychiatrist to determine whether he is incompetent to stand trial has a privilege against self-incrimination and must be so informed if any information obtained by the psychiatrist is to be used in the sentencing phase of the trial. Estelle v. Smith, 451 U.S. 454 (1981).

103. 405 U.S. 245 (1972).

104. Lessard v. Schmidt, 349 F. Supp. 1078, 1101 (E.D. Wis. 1972) (three-judge court), vacated and remanded on other grounds, 414 U.S. 473 (1974), on remand, 379 F. Supp. 1376 (1974), vacated and remanded on other grounds, 421 U.S. 957 (1975), on remand, 413 F. Supp. 1318 (1976).

105. In the vast majority of instances, there is probably very little similarity between police interrogations and psychiatric interviews. Thus, we should feel free, at least as a threshold matter, to indulge in a presumption of good faith on the part of psychiatrists which we may not wish, as a matter of policy, to accord police. The latter have as their primary objective the partisan one of obtaining an arrest and conviction, whereas the psychiatrist ought to be assumed to be attempting to arrive at a less partisan objective of determining whether a given individual is mentally ill and/or dangerous. To some extent, the right to remain silent, per se, in psychiatric examinations for civil commitment proceedings is not the crux of the matter because the patient has the power not to speak to a psychiatrist, even if he has no right not to. Although there are some psychiatrists (as well as other persons) who would either deny the existence of free will generally or claim that all or some forms of mental illness seriously compromise, if they do not destroy, free will, this deterministic view is largely incompatible with basic assumptions of Anglo-American law. The legal system, however, most notably in the criminal context, does recognize exceptional situations in which individuals are excused from the normal sanctions for their conduct. Similarly, a potential psychiatric patient who was found, as a result of mental illness, to be unable to resist the temptation to speak might be found unable to execute a legally valid waiver of his privilege against self-incrimination, assuming arguendo that the privilege exists in psychiatric interviews.

Exercise of the power not to speak may depend on knowledge of the fact that no sanctions may be applied for a failure to speak. This then raises several issues. May sanctions of any sort be imposed against a patient who refuses to cooperate in the psychiatric examination? This issue was, in effect, adjudicated in McNeil v. Director, Patuxent Inst., 407 U.S. 245 (1972), in which the Court held that an individual convicted of a crime and sentenced to a maximum term of five years could not be held beyond the expiration of that term despite the fact that he refused to cooperate on numerous occasions in the psychiatric evaluation which the state wished to perform to determine if he were a "defective delinquent." Had the 
the privilege against self-incrimination clause of the fifth amendment and the right to assistance of counsel secured by the sixth amendment as applied to the states through the due process clause of the 14th amendment, though on occasion such litigation has proceeded on due process grounds without reference to the specific guarantees of the fifth and sixth amendments. ${ }^{106}$ Litigation under state constitutions might proceed on the same bases. The obvious choices would be express selfincrimination and right-to-counsel provisions, with resort to a general due process clause in support of the more specific sources (or in lieu of them) should a court be reluctant to apply a privilege in noncriminal proceedings. ${ }^{107}$ The decisions of the respective state supreme courts on these issues in the criminal context, if there are any such decisions in a given jurisdiction, may be useful guides to potential mental health litigants. These decisions may be of little value where the state court has been unwilling, in the case of the criminally accused, to construe its self-incrimination and/or right-to-counsel provisions as protectively as the Supreme Court has construed those provisions of the Federal Constitution. If such is the case, the state supreme court is unlikely to be more favorably disposed to civil mental health litigants. Where, however, the state court has been equally or more protective of the rights of the criminally accused under the state constitution than the Supreme

defendant been a defective delinquent, under state law he could have been incarcerated for "treatment" for an indeterminate period. Id. at 246-47.

May proponents of commitment draw adverse inferences from the patient's silence at the commitment hearing? May proponents draw an inference from silence that if the patient spoke, what he said would be "incriminating" (i.e., tending toward commitment), or that silence in the face of a question by a psychiatrist is in itself evidence of mental disorder? In $M c N e i l$, the state argued before the Supreme Court that "petitioner is probably a defective delinquent, because most noncooperators are." Id. at 251. The Court stopped short of holding that such an inference could be drawn, holding instead that the "argument proves too much. For if the Patuxent staff members were prepared to conclude, on the basis of petitioner's silence and their observations of him over the years, that petitioner is a defective delinquent, then it is not true that he has prevented them from evaluating him." Id.

106. See, e.g., Lessard v. Schmidt, 349 F. Supp. 1078, 1101 (E.D. Wis. 1972): "Wisconsin may not, consistent with the basic concerns of due process, commit individuals on the basis of their statements to psychiatrists in the absence of a showing that the statements were made with 'knowledge' that the individual was not obliged to speak."

107. Typically, state constitutional self-incrimination provisions are, like the fifth amendment's protection, limited by their terms to criminal cases. However, a court might be willing to overlook this express limitation, reasoning as did the Supreme Court in In re Gault, 387 U.S. 1 (1967), that

the privilege does not turn upon the type of proceeding in which its protection is invoked, but upon the nature of the statement or admission and the exposure which it invites. The privilege may, for example, be claimed in a civil or administrative proceeding, if the statement is or may be inculpatory. Id. at 49. The California Supreme Court, however, was not willing to overlook this express limitation in either the California constitution or the Federal Constitution in a case involving the commitment of a mentally retarded individual, except as to matters "which may tend to incriminate him in criminal activity" not the subject of the instant proceedings, which were civil in nature. Cramer v. Tyars, $23 \mathrm{Cal} .3 \mathrm{~d}$ 131, 588 P.2d 793, 796, $151 \mathrm{Cal}$. Rptr. 653 (1979). Compare supra note 86. A few states, however, have provisions which do not on their face limit the applicability of the provision to criminal proceedings. See, e.g., GA. Const. art. I, § 1, 1 1 ("in any matter"); OKLA. Const. art. II, § 21; R.I. Const. art. I, § 13 ("in a court of common law').

Few state statutes confer a privilege against self-incrimination. One that does is lll. REv. STAT. ch. 911/2, ๆ 3-208 (1979), which also requires an examining physician to "inform the person being examined in a simple comprehensible manner . . . that he does not have to talk to the examiner; and that any statements he makes may be disclosed at a court hearing on the issue of whether he is subject to involuntary admission." Further, the statute also includes an exclusionary rule in situations in which the warning has not been given. See, e.g., In re Rizer, 409 N.E.2d 383 (Ill. App. 1980). But compare Commonwealth ex rel. Platt v. Platt, 266 Pa. Super. 276, 404 A.2d 410 (1979). 
Court has been under the Federal Constitution, the state court may also be more receptive to the claims for protection advanced by mental health litigants.

Where there is little evidence of the state court's attitude toward these provisions of its own constitution, a prediction may be ventured on the basis of the state court's record in applying federal constitutional provisions for the protection of the criminally accused. If the state court has a record of construing such provisions more narrowly than the Supreme Court, it is not likely to be any more liberal in its construction of its own constitution unless that constitution affords some more particularized protection than does the Federal Constitution. By contrast, if the state court has been more liberal in its construction of the Federal Constitution than the Supreme Court, it may be more likely to continue this trend in construing analogous provisions of the state constitution in mental health litigation.

The lower courts have also been unreceptive to claims of a constitutional right to jury trial in civil commitment cases. ${ }^{108}$ No court has ever held, on the basis of the Federal Constitution, that such a right exists. Such holdings are based on McKeiver v. Pennsylvania ${ }^{109}$ in which the Supreme Court held that due process does not require a jury trial in juvenile delinquency proceedings. Since the Court in Addington refused to require as stringent a burden of proof in civil commitment cases as in juvenile delinquency adjudications, ${ }^{10}$ there can be little doubt that the Court would refuse to require jury trials in civil commitment cases.

State courts have, however, been slightly less unwilling to require jury trials on the basis of state constitutional provisions, sometimes bootstrapped by state statutes. ${ }^{11}$ In litigation brought under a state constitution, any express provision

108. Whether or not a respondent in a civil commitment hearing is tactically better off with a jury trial than without is a question wholly separate from whether or not there is a constitutional right to jury trial. My own view is that, on balance, most respondents are better off being tried by a judge than a jury. See Ziemann, Incompetency and Commitment Proceedings, in 8 AM. JUR. TRIALs $\S 47$, at 547 (1965). Of course it is probably better to have a choice than to be compelled to go without jury trial since in some cases counsel for the respondent or the respondent himself may have strong reasons for preferring a jury. There is always the further problem that where jury trial exists, the right may not be waivable without consent of the state and/or the court. This is the general rule in federal criminal cases, both as a matter of court rule, see FED. R. CRIM. P. 23(a), and constitutional law. See Serfass v. United States, 420 U.S. 377 (1975). The same is generally true in state criminal proceedings. See generally Annot. 51 A.L.R.2D 1346 (1957).

109. 399 U.S. 925 (1970).

110. 441 U.S. at 428.

11. "Although the United States Supreme Court has not directly faced this issue, the courts which have have rejected the contention." In re Mills, 36 Or. App. 727, 730-31, 585 P.2d 1143, 1144-45 (1978) (collecting cases). The reasoning underlying the refusal to require jury trial under the Federal Constitution in civil commitment cases is that "[s]uch proceedings are not considered 'suits at common law' and therefore no jury trial is mandated by the Seventh Amendment . . . . Ward v. Booth, 197 F.2d 963, 966 (9th Cir. 1952)." Id. at 1145. Nor has jury trial "in this context," id., been deemed to be "a necessary element of fundamental fairness guaranteed by the due process clause." Id. The court also held that the Oregon civil commitment statute is not invalid under the Oregon constitution, art. I, $\S 17$, which provides (in language similar to that of many other state constitutions) that "[i]n all civil cases, the right of Trial by Jury shall remain inviolate." Id. at 1144 .

Many states provide a statutory right to jury trial in civil commitment cases, even when not constitutionally obligated. See Note, The Confuement of Mabel Jones: Is There a Right to Jury Trial in Civil Commitment Proceedings, 6 FLA. ST. U.L. Rev. 103, $113-14$ n.60 (1978) (collecting statutes); Slate Laws Goveming Civil Commitment, 3 MENTAL Disability L. REP. 206 (1979) (collecting statutes). There has been a good deal of litigation under the California constitution involving the right to a jury trial in commitment cases. The state constitution requires a unanimous verdict in certain instances. Estate of Roulet, $23 \mathrm{Cal}$. 3d 219, 590 P.2d 1, 152 Cal. Rptr. 425 (1979) (proceedings for the appointment of a conservator); People v. Burnick, 14 
guaranteeing the right to a trial by jury will undoubtedly be helpful. In the absence of such a provision, reliance upon the state due process clause may afford some chance of success. Finally, in lieu of an express provision (or in addition to it), an equal protection argument should be made where a state statute accords certain kinds of litigants the right to a jury trial-for example, criminal defendants, but especially juvenile delinquents and, a fortiori, litigants in ordinary civil cases-but either denies or fails to expressly grant this right in civil commitment hearings. ${ }^{112}$

Another important issue in the commitment process is the concept of the "least restrictive alternative,"113 a concept also relevant to decisions involving the treatment of patients in psychiatric institutions, the release of patients from an institution, and the transfer of patients to other institutional settings. ${ }^{114}$ While there is little doubt about the applicability of the general constitutional concept in the mental health context, ${ }^{115}$ the full range and implications of the concept have yet to

Cal. 3d 306, 535 P.2d 352, 121 Cal. Rptr. 488, (1975) (commitment as a mentally disordered sex offender); People v. Feagley, 14 Cal. 3d 388, 535 P.2d 373, 121 Cal. Rptr. 509 (1975) (commitment as a mentally disordered sex offender); People v. Thomas, 19 Cal. 3d 630, 566 P.2d 228, 139 Cal. Rptr. 594 (1977) (commitment as a drug addict). However, a conservatee is not constitutionally entitled to a jury trial at periodic rehearings. Barber v. San Bernardino Super. Court, 113 Cal. App. 3d 955, 170 Cal. Rptr. 353 (1980). As to the existence of the basic right to jury trial itself, due process and equal protection require a jury trial when the state seeks to extend the commitment of a mentally deficient ward of the state beyond the release date initially established. In re Gary W., 5 Cal. 3d 296, 486 P.2d 1201, 96 Cal. Rptr. 1 (1971); People v. Smith, 5 Cal. 3d 313, 486 P.2d 1213, 96 Cal. Rptr. 13 (1971).

112. Cf, e.g., In re Gary W., 5 Cal. 3d 296, 486 P.2d 1201, 96 Cal. Rptr. 1 (1971); People v. Smith, 5 Cal. 3d 313, 486 P.2d 1213, 96 Cal. Rptr. 13 (1971). In both of these cases the precise grounds for and the reasoning behind the holding are unclear. The California Supreme Court relied both on due process and equal protection clauses, and did not clearly distinguish between the state and federal constitutions in holding that a ward of the California Youth Authority has a right to a jury trial when the state seeks to delay the individual's release date.

113. See generally Chambers, Altematives to Civil Commitment of the Mentally Ill: Practical Guides and Constitutional Imperatives, $70 \mathrm{MiCH}$. L. REv. 1107 (1972).

Some state constitutional provisions besides the due process clause-which is the source in the Federal Constitution of the least restrictive alternative - may be helpful. See supra note 91 .

114. I use the word "institution," perhaps somewhat more broadly than it often is used, to apply to any kind of setting in which an individual receives psychiatric treatment pursuant to legal process or pressure from mental health authorities. Thus, I mean to include in the definition of "institution" inpatient psychiatric hospitalization, partial hospital programs, compelled or cajoled attendance at psychiatric outpatient (especially medication) clinics, and residence in half-way houses, community living arrangements, or buildings bearing whatever euphemism the authorities are currently bestowing upon them. (The current jargon is "community living arrangements," often shortened to "CLA's." See Halderman v. Pennhurst State School \& Hosp., 612 F.2d 84, 93 (3d Cir. 1979).)

115. Lake v. Cameron, 364 F.2d 657 (D.C. Cir. 1966), was the first case to apply the doctrine in the mental health field, though in that particular case, it was statutorily grounded. Subsequently, in Covington v. Harris, 419 F.2d 617 (D.C. Cir. 1969), the court invoked the doctrine on constitutional grounds. Accord Welsch v. Likins, 373 F. Supp. 487 (D. Minn. 1974); Lessard v. Schmidt, 349 F. Supp. 1078 (E.D. Wis. 1972); Wyatt v. Stickney, 325 F. Supp. 781 (M.D. Ala. 1971). But see State v. Sanchez, 80 N.M. 438 , 457 P.2d 370 (1969), appeal dismissed for want of a substantial federal question sub nom. Sanchez v. New Mexico, 396 U.S. 276 (1970).

The Supreme Court has not ruled on the constitutional basis of the least restrictive alternative principle in mental health cases, though the recently decided case of Pennhurst State School \& Hosp. v. Halderman, 451 U.S. 1 (1981), involved an issue of a statutorily based least restrictive alternative. On remand, the constitutional issue did not resurface. The validity of the concept, however, will remain in doubt until the Supreme Court definitively rules. Furthermore, in Rennie v. Klein, 653 F.2d 836 (3d Cir. 1981), a case ruling on the right of involuntarily civilly committed patients to refuse treatment, the court expressed some 
be judicially explored. ${ }^{116}$

\section{Rights of Involuntarily Committed Persons}

There are numerous issues concerning the rights of persons who have been committed to treatment in psychiatric institutions. Many of these issues have been litigated successfully under the Federal Constitution, but very few have been reviewed by the Supreme Court. Thus, the viability of the federal constitutional

doubt about the practicability of the concept, which it referred to as "least intrusive means," in the mental health context:

The least intrusive means standard does not prohibit all intrusions. It merely directs attention to and requires avoidance of those which are unnecessary or whose cost benefit ratios, weighed from the patient's standpoint, are unacceptable. . . .

This is not to say that the least intrusive means requires hourly or daily judicial oversight. Obviously that would be an unworkable standard. . . .

[P]romulgation of the standard merely serves to advise the psychiatric community that a conscious weighing of the constitutional liberty interest in any determination of proper treatment alternatives is necessary.

Id. at 847. Therefore, even the threshold issue of the applicability of the least restrictive alternative to mental health questions ought to be explored on state law as well as federal grounds. One court has recently done so. See Patients, C.T. v. Camden County Bd. of Chosen Freeholders, No. L-33417-74 P.W. (N.J. Super. Ct. Law Div. Jan. 19, 1981), holding that patients who had been ordered discharged by a court from a psychiatric hospital but whose confinement had been continued because of a lack of community facilities to which they could be discharged, id., slip op. at 3-4, have a right under state law "to suitable aftercare treatment in community mental health and other supportive facilities." Id., slip op. at 12. The court did not, however, clarify whether the right could be grounded exclusively on either the state statute or the state constitution, holding that the right derives from both.

116. For instance, does the least restrictive alternative apply only in the initial decision to hospitalize vel non, or does it also apply to treatment decisions involving the question of whether to use drugs or not, or whether to use one drug over another? The Third Circuit, in three recent cases, has held that it is applicable not merely when the initial hospitalization decision is made, but in the institution as well. See Rennie v. Klein, 653 F.2d 836, 847 (3d Cir. 1981) (least restrictive alternative applies to medications); Scott v. Plante, 641 F.2d 117, 129-31 (3d Cir. 1981) (least restrictive alternative applies to level of security to be used in confining criminally committed person); Youngberg v. Romeo, $102 \mathrm{~S}$. Ct. 2452 (1982) vacating and remanding 644 F.2d 147 (3d Cir. 1980) (least restrictive alternative applies to physical restraints and to treatment plans, but not to day-to-day treatment decisions). Is the determination of "restrictiveness" to be made by reference to objective standards or the patient's subjective preferences? See, e.g., Rennie v. Klein, 653 F.2d at 847 (" $t]$ he least intrusive means standard . . . merely directs attention to and requires avoidance of those [intrusions] which are unnecessary or whose cost benefit ratios, weighed from the patient's standpoint, are unacceptable") (emphasis added). What is an "alternative"? Must it exist in theory to qualify? Must it exist in the geographic locale or jurisdiction in question? Do financial considerations determine whether something is an "alternative"? See, e.g., N.J. STAT. ANN. \$ 30:4-24.1 (West 1970), cited in Patients, C.T. v. Camden County Bd. of Chosen Freeholders, No. L-33417 P.W. (N.J. Super. Ct. Law Div. Jan. 19, 1981): "Every individual who is mentally ill shall be entitled to . . medical care and other professional services in accordance with accepted standards, provided however that this shall not be construed to require capital construction...." This restriction is contained in the statutory section immediately preceding that which recognizes the right to treatment in "the least restrictive conditions necessary to achieve the purposes of treatment." N.J. STAT. ANN. § 30:4-23.2(e)(2) (West 1970).

Questions also exist concerning the standard and burden of proof on least restrictive alternative. Although Addington might seem to have settled the standard of proof issue, the precise issue was not presented for decision since least restrictive alternative was not a statutory ground for commitment in Texas, nor did the petitioner claim that it was constitutionally required that it be a ground for commitment. Furthermore, a court might be willing to hold that although a certain standard of proof must be met with respect to substantive grounds for commitment, a lesser burden will suffice for least restrictive alternative, assuming that least restrictive alternative is not itself constitutionally required as a ground for commitment. See, e.g., Proctor v. Butler, 117 N.H. 927, 380 A.2d 673, 677-78 (1977). But see Chambers, Altematives to Civil Commitment of the Mentally Ill: Practical Guides and Constitutional Imperatives, $70 \mathrm{MiCH}$. L. REV. 1107, 1151-54 (1972). 
basis of these rights is uncertain. Further, some of these issues have not had cordial receptions in the lower federal courts. Therefore, litigation of these issues in the future ought to proceed both on the basis of the Federal Constitution and appropriate state constitutional provisions.

Much of the litigation arising under the Federal Constitution has been based on the due process clause of the 14 th amendment, sometimes exclusively and sometimes in conjunction with other constitutional provisions such as the first amendment or even more specific provisions such as the sixth amendment right to counsel. These issues include the right to treatment ${ }^{117}$ and the right to refuse treatment, ${ }^{118}$ the right to be treated in the least restrictive setting, ${ }^{19}$ rights involving transfer ${ }^{120}$ and release from the institution, ${ }^{121}$ the rights to work, ${ }^{122}$ not to work, ${ }^{123}$ or to be compensated for work, ${ }^{124}$ and financial rights. ${ }^{125}$ Often other broad constitutional provisions have been invoked in conjunction with or instead of due process such as equal protection, privacy, and cruel and unusual punishment. Those issues that have involved rights of expression have usually implicated the first amendment, as well as due process, equal protection, and privacy, and some litigation has relied on even more specific guarantees, such as the right to counsel.

117. See supra notes $28,31,92$.

118. See supra note 17.

119. See, e.g., Halderman v. Pennhurst State School \& Hosp., 446 F. Supp. 1295 (E.D. Pa. 1977) (state and federal statutory rights and federal constitutional right of institutionalized mentally retarded persons to be treated in the least restrictive setting), affd in part and rev'd in part, $612 \mathrm{~F} .2 \mathrm{~d} 84$ (3d Cir. 1979) (federal statutory right to be treated in the least restrictive setting), rev'd and remanded, 451 U.S. 1 (1981); Dixon v. Weinberger, 405 F. Supp. 974 (D.D.C. 1975) (statutory right of institutionalized mentally ill persons to be treated in facilities outside of institution where such treatment is medically appropriate); see also infra note 137; Preparation and Trial of a Civil Commitment Case, 5 Mental Disability L. ReP. 201, 209-10 (1981). Cf. Cases to Deinstitutionalize Mentally Retarded Persons, 5 Mental Disability L. ReP. 142 (1981).

120. A hearing must be accorded before an individual may be transferred from a prison to a psychiatric hospital, Vitek v. Jones, 445 U.S. 480 (1980), though not in an emergency. New York ex rel. Overton v. Director, Cent. N. Y. Psychiatric Center, 418 N.Y.S.2d 254 (Sup. Ct. 1979); In re Linder, 419 N.Y.S.2d 375 (App. Div. 1979). However, when a pretrial detainee is transferred from a mental hospital to a prison, a hearing is not required. Santori v. Fong, 484 F. Supp. 1029 (E.D. Pa. 1980). It is not clear whether a hearing is constitutionally required when the transfer is within a hospital (or a state hospital system) to more restrictive wards. See Christy v. Hammel, 87 F.R.D. 381 (M.D. Pa. 1980) (denying a motion to dismiss). The case was ultimately settled by consent, the state agreeing to provide "some procedural protections . . . " 5 Mental. Disability L. ReP. 106 (1981).

121. See, e.g., Frederick v. Mulcahy, No. 76-257 (D. Vt. filed Dec. 16, 1979) (challenging state system of conditional discharge). The case was dismissed in light of statutory and regulatory changes, 4 MENTAL Disability L. REP. 170 (1980); Meisel v. Kremens, 405 F. Supp. 1253 (E.D. Pa. 1975) (constitutionality of conditional discharges).

122. See, e.g., Davis v. Balson, 461 F. Supp. 842, 853-54 (N.D. Ohio 1978).

123. See, e.g., Jobson v. Henne, 355 F.2d 129 (2d Cir. 1966) (right not to perform nontherapeutic work); Davis v. Balson, 461 F. Supp. 842, 852 (N.D. Ohio 1978) (right not to perform counter-therapeutic work); Downs v. Department of Pub. Welfare, 368 F. Supp. 454, 458-59 (E.D. Pa. 1973) (right not to perform counter-therapeutic work).

124. See, e.g., Jobson v. Henne, 355 F.2d 129 (2d Cir. 1966) (constitutional right); Davis v. Balson, 461 F. Supp. 842, 852 (N.D. Ohio 1978) (constitutional right); Downs v. Department of Pub. Welfare, 368 F. Supp. 454, 459 (E.D. Pa. 1973) (statutory right); Souder v. Brennan, 367 F. Supp. 808 (D.D.C. 1973) (statutory right).

125. Vecchione v. Wohlgemuth, 377 F. Supp. 1361 (E.D. Pa. 1974), affd, 558 F.2d 150 (3d Cir. 1977), cert. denied, 434 U.S. 943 (1977) (constitutionality of state's control of funds of institutionalized persons); Bridges v. Virginia Dep'r of Mental Health \& Mental Retardation, No. 43385 (Va. Cir. Ct., July 12, 1979) (dismissing constitutional challenge to statute requiring spouse to pay costs of institutionalization), appeal denied, (Va. Sup. Ct. April 14, 1980), appeal dismissed, 449 U.S. 803 (1980). 
Where litigation rests upon broad guarantees such as due process, proceeding under a state constitution should be similar to proceeding under the 14th amendment of the Federal Constitution. The state due process clause merely will give a state court greater latitude in defining rights, or if the litigation is in federal court under pendent jurisdiction, the state constitution may provide the trial court with a means for avoiding any unfavorable law of that circuit. On the other hand, the federal court will be reluctant to decide state law questions of first impression. The litigation itself will be similar to litigation based exclusively on the 14th amendment, with two possible exceptions. Favorable state court cases construing the state due process clause may also be relied upon, and favorable state court doctrinal differences-for example, a state court that classifies a particular right as a "fundamental" one where the federal courts (and especially the Supreme Court) have viewed it otherwise-may also prove helpful. ${ }^{126}$ The same is true of litigation based on other broad constitutional provisions such as freedom of expression, equal protection, privacy, and cruel and unusual punishment. Some state courts may also have a history of construing certain state constitutional provisions in a manner more protective of individual rights than courts have with an analogous federal constitutional provision. ${ }^{127}$

Where an asserted right finds support in more specific constitutional guarantees, ${ }^{128}$ state constitutional provisions may prove even more helpful. However, whether or not the state provision will affect the outcome of the litigation may depend more on the attitude and tradition of the state court with respect to that particular guarantee than on the precise language of the state provision or even its mere existence. For instance, there has been some litigation attempting to establish a right to have counsel (or "counsel substitute") present in "staffings."129

126. Compare for example, San Antonio Indep. School Dist. v. Rodriguez, 411 U.S. 1 (1973), in which the Supreme Court in upholding a school funding system against a challenge that it denied equal protection of the law held that education is not a "fundamental" right, with Serrano v. Priest, 18 Cal. 3d 728, 557 P.2d 929, 135 Cal. Rptr. 345 (1976), in which the California Supreme Court, when confronted with a similar issue, held that the right to education is "fundamental" and invalidated the school financing system on the basis of the state equal protection guarantee.

127. The California courts are the prime example. See, e.g., Department of Mental Hygiene v. Kirchner, 29 Cal. Rptr. 312 (Cal. App. 1963), uacaled and remanded, $60 \mathrm{Cal}$. 2d 716, 388 P.2d 720, 36 Cal. Rptr. 488 (1964), vacated and remanded, 380 U.S. 194 (1965), on remand, 60 Cal. 2d 586, 400 P.2d 321, 43 Cal. Rptr. 329 (1965), discussed supra text accompanying notes 77-80. See also Ravin v. State, 537 P.2d 494 (Alaska 1975), in which the court held, on the basis of the state constitutional provision securing a right of privacy (art. I, \& 22) that the "possession of marijuana by adults at home for personal use is constitutionally protected . . . ." Id. at 511. Although the court did not so hold, it did suggest-by referring to other cases which had rejected a federal constitutional right to privacy as supporting such a claim, see id. at $502 \&$ $\mathrm{nn} .32-33$ (collecting cases) - that there is no federal constitutional privacy right to use marijuana.

128. One state constitution has a provision dealing particularly with civil rights of institutionalized mentally disabled persons. See MoNr. ConsT. art. XII, § 3(2): "Persons committed to any . . . institutions shall retain all rights except those necessarily suspended as a condition of commitment. Suspended rights are restored upon termination of the state's responsibility." Although probably intended to apply specifically to civil competency (contractual, testamentary, and testimonial), there is no reason why the provision need be construed in that narrow a fashion.

129. "Staffing is a procedure whereby a patient is reviewed by the staff members assigned to him to determine the disposition of observation and indefinite commitment cases." Davis v. Balson, 461 F. Supp. 842 (N.D. Ohio 1978). Staffings may also be held to determine whether to transfer or discharge a patient, or to make alterations in the patient's treatment plan.

A "staffing" is nothing more than a meeting-a meeting at which those staff members who have 
Although an attempt was made to ground the right in due process, ${ }^{130}$ the court treated the claim as if it were also grounded in the more specific right to counsel. ${ }^{131}$ State constitutional guarantees of the right to counsel, and possibly the right to cross-examine witnesses, ${ }^{132}$ may bootstrap not only claims based on federal constitutional provisions, but also on state due process claims. Similarly, where a claim implicates federal first amendment interests-for example, asserted rights to visitors, ${ }^{133}$ uncensored incoming ${ }^{134}$ and outgoing ${ }^{135}$ mail, access to books, television and radio, ${ }^{136}$ and telephones, ${ }^{137}$ and religious practice ${ }^{138}$-the first amendment equivalent in the state constitution should be invoked to bolster the claim. ${ }^{139}$

\section{Rights in the Community}

Individuals who suffer from and have suffered from a mental disability are often the victims of discrimination of various kinds. ${ }^{140}$ Discrimination occurs

responsibility for a particular patient's care discuss the patient's condition and make determinations or recommendations concerning diagnosis, treatment, and conditions of confinement.

130. Davis v. Balson, 461 F. Supp. 842, 859 (N.D. Ohio 1978).

131. Id. at $859-60$.

132. Many state constitutions contain a provision in the bill of rights pertaining to the rights of persons accused of crimes. These provisions often list a number of separate rights such as notice, counsel, cross-examination, the right to be heard, to call witnesses, and to have compulsory process for obtaining witnesses. See, e.g., WIS. CONST. art. I, \$7. Although not applicable by their terms to civil commitments, they may be persuasive to courts of the kinds of rights which persons ought to have in civil commitment hearings. See supra note 107.

133. See, e.g., Eckerhart v. Hensley, 475 F. Supp. 908, 923-25 (W.D. Mo. 1979) (restrictions imposed on visitors so extreme as to be not reasonably related to legitimate interests in security or orderly hospital administration); Wyatt v. Stickney, 344 F. Supp. 373, 379 (M.D. Ala. 1972) (qualified right to visitors; unrestricted right to visitation with attorneys and physicians).

134. See, e.g., Eckerhart v. Hensley, 475 F. Supp. 908, 923-25 (W.D. Mo. 1979) (screening of incoming mail for contraband out of presence of recipient is not unconstitutional); Davis v. Balson, $461 \mathrm{~F}$. Supp. 842, 864-65 (N.D. Ohio 1978) (opening of incoming mail outside the presence of recipient unconstitutional); Wyatt v. Stickney, 344 F. Supp. 373, 379-80 (M.D. Ala. 1972) (qualified right to receive sealed mail).

135. See, e.g., Davis v. Balson, 461 F. Supp. 842, 867 (N.D. Ohio, 1978) (restriction on outgoing mail addressed to "strange people" furthers no legitimate government interest); Wyatt v. Stickney, 344 F. Supp. 373, 379 (M.D. Ala. 1972) (unrestricted right to send sealed mail).

136. See, e.g., Davis v. Balson, 461 F. Supp. 842, 865-66 (N.D. Ohio 1978) (rule permitting patients to receive publications only if sent by the publisher not sufficiently related to security).

137. See, e.g., Eckerhart v. Hensley, 475 F. Supp. 908, 923-25 (W.D. Mo. 1979) (restrictions imposed on access to telephones so extreme as to be not reasonably related to legitimate interests in security or orderly hospital administration); Wyatt v. Stickney, 344 F. Supp. 373, 379 (M.D. Ala. 1972) (qualified right of access to telephones; unrestricted right to telephone communication with attorneys and private physicians).

138. See, e.g., Wyatt v. Stickney, 344 F. Supp. 373, 381 (M.D. Ala. 1972) (patients have a right to religious worship and a right not to be coerced into engaging in religious activities).

139. It is also worth considering whether these claims should be brought as due process claims "bootstrapped" by free expression and religious freedom provisions, or whether they should be brought as pure free expression or religious freedom claims. Professor Emerson argues that such claims are more likely to succeed as bootstrapped due process claims than as free expression claims. See T. EMERSON, THE SYSTEM OF FREEDOM OF EXPRESSION (1970). Every state constitution has a provision dealing with freedom of expression and religious freedom.

140. Persons who exhibit symptoms of mental illness may suffer discrimination because they are perceived as being strange, regardless of their ability to perform a particular job, for example, or to repay a loan, or to live peacefully in an apartment. Some persons who are free of symptoms of mental illness may manifest symptoms of the treatments for the illness, which makes them appear to be strange. This is especially true when persons who have schizophrenia are treated with neuroleptic medications, which often results in tardive dyskinesia, though it may occur with other treatments and other illnesses too. 
against those who have been hospitalized and discharged; against those who have been discharged and are currently receiving care in outpatient clinics, community treatment facilities, or from private mental health practitioners; against those who have never been hospitalized but who have received or are receiving treatment on an outpatient basis; and against those who are mentally ill but have never been treated in any way. ${ }^{141}$ Discrimination occurs in many realms: housing, employment, education, and credit are among the more important, ${ }^{142}$ but such discrimination also occurs in small ways such as when retail businesses will not serve persons whom they identify as being mentally ill. This discrimination occurs for many reasons, some based on misconception and some on prejudice, but some based on rational grounds.

Numerous efforts-many legislative, some judicial, and many of a nonlegal, political variety - have been undertaken in the decade of the 1970's to eliminate or ameliorate the harsh effects of this discrimination. Several important pieces of legislation designed to eliminate discrimination against the mentally disabled or to provide them with equal opportunities in certain spheres of activity were enacted by Congress. ${ }^{143}$ However, just as with constitutionally based rights, the Supreme Court has construed some of this legislation in a manner unfavorable to the rights of the mentally disabled. ${ }^{144}$ In contrast, the lower federal courts have been far more receptive to these statutorily based claims. ${ }^{145}$ The interpretation of these

Tardive dyskinesia is a neurological side effect which may appear after prolonged use of anti-psychotic drug treatment. The disease is the outcome of a complex patient-drug interaction which is not currently well understood. The overt symptoms of tardive dyskinesia include certain involuntary motor movements, particularly of the face, lips, and tongue. Tardive dyskinesia can also cause the involuntary movement of fingers, hands, legs and the pelvic area. In its most progressive state, the disease can interfere with swallowing and can affect all motor activity. While in mild cases the disease can simply be a source of embarassment, it can be physically and psychologically disabling. Until very recently, tardive dyskinesia was considered irreversible. Some studies now suggest that in certain cases it can be effectively treated.

Rogers v. Okin, 473 F. Supp. 1342, 1360 (D. Mass. 1979). Cf. Clites v. Iowa, Law No. 42674 (Iowa Dist. Ct., Aug. 7, 1980) (awarding damages of $\$ 760,000$ to a patient who developed tardive dyskinesia), noted in 5 Mental Disabllity L. ReP. 110 (1981).

141. See, e.g., N.Y. Times, Feb. 19, 1978, § 21, at 26, col. 2; N.Y. Times, July 22, 1978, at 21, col. 3 .

142. See, e.g., N.Y. Times, Feb. 11, 1978, at 25, col. 4; N.Y. Times, Feb. 1, 1981, § 11, at 26, col. 3.

143. See supra note 3 .

144. See supra note 6 .

145. "Every court of appeals and district court . . . that has considered this question has held that a private right of action exists under $\$ 504$ [of the Rehabilitation Act of 1973, 29 U.S.C. $\S 794$ (1976 \& Supp. II 1978)]." Pushkin v. Regents, 658 F.2d 1372, 1377 (10th Cir. 1981). However, the courts of appeals have been unanimous in holding that there is no private right of action under $\S 503$ of the Rehabilitation Act. See Simpson v. Reynolds Metals Co., 629 F.2d 1226 (7th Cir. 1980); Rogers v. Frito Lay, Inc., 611 F.2d 1074 (5th Cir. 1980) (collecting cases), cert. denied, 449 U.S. 889 (1980); Hoopes v. Equifax, Inc., 611 F.2d 134 (6th Cir. 1979). In addition, the Ninth Circuit has heard oral argument in Fisher v. City of Tucson, Civ. No. 77-37TUC (D. Ariz. 1977), but has not yet rendered a decision.

The status of this issue before the Supreme Court is ambiguous at best. The Court held in Maine $v$. Thiboutot, 448 U.S. 1 (1980), that there is a private right of action to redress a statutory violation brought under 42 U.S.C. $\S 1983$. The issue of whether or not a private right of action exists under the Developmentally Disabled Assistance and Bill of Rights Act was avoided by the Court in Pennhurst State School \& Hosp. v. Halderman, 451 U.S. 1 (1981), but Justice Blackmun's concurring opinion reads the majority opinion as "intimat[ing] that [the majority of the Court] will not view kindly any future positive holding in that direction." Id. at 32. A lower federal court has held that the Developmentally Disabled Assistance and Bill of Rights Act does create a private right of action. See Garrity v. Gallen, 522 F. Supp. 171 (D.N.H. 1981). 
statutes by the Supreme Court is further impetus for looking to state constitutions (and legislation) to secure the rights of the mentally disabled. There is, however, an even more compelling reason for looking to state constitutions when concerned with the rights of the mentally disabled in the community, as opposed to the commitment process or involuntary treatment settings. In neither of these areas is litigation based on state constitutions as likely to bring judicial relief to mental patients. Because much discrimination is perpetrated by private individuals or organizations rather than state agents (as is ordinarily the case in the commitment process and involuntary treatment settings) federal constitutional law is severely handicapped in reaching and dealing with discrimination against mental patients who are residents of the ordinary workaday world. ${ }^{146}$ By contrast, state constitutional guarantees of individual liberties may secure such liberties against private action as well as state action. ${ }^{147}$ In fact, there have already been a few important cases in this area based on state constitutional guarantees. ${ }^{148}$

One area in which state law-not just constitutional, but statutory and common law as well-could play an important role is in discrimination against

146. Where the basis of alleged discrimination is racial, there is a right of action under 42 U.S.C. $\S 1985(3)$ (1976) against private parties since the 13th amendment empowers Congress to legislate against private racial discrimination. Griffin v. Breckenridge, 403 U.S. 88 (1971). But where the basis of the discrimination is not racial, the constitutional basis must be in the 14th amendment, and it is an open question whether $\S 5$ of the 14th amendment empowers Congress to legislate against private action.

147. The extent to which state constitutional protections of individual rights bar discrimination by private parties not acting under color of law, as opposed to discrimination by state agents, is not well settled. Some state constitutional provisions explicitly protect against discrimination by private actors, others explicitly limit protection to discrimination by state agents. Compare ILL. CoNST. art. I, $\S 17$ (prohibiting discrimination by private parties in employment and in sale or rental of property on basis of race, color, creed, national ancestry, and sex) and $\S 19$ (prohibiting discrimination by private parties in sale or rental of property and in employment on basis of handicap) with id. $\S 18$ (prohibiting discrimination by governmental entities on account of sex). State constitutional provisions, as applied, may infringe not only on federal constitutionally protected individual rights but on constitutional powers of a branch of the Federal Government, such as the commerce power. For instance, if a state were to hold that its constitution conferred a right to use a particular drug the production, transportation, sale, or distribution of which was prohibited by the Federal Government, such a holding might conflict with the commerce power. Compare, e.g., People v. Privitera, 141 Cal. Rptr. 764 (Cal. App. 1978) (California constitutional right of privacy permits licensed physician to prescribe laetrile), rev'd, 23 Cal. 3d 697, 591 P.2d 919, 153 Cal. Rptr. 431 (1979), with United States v. Rutherford, 442 U.S. 544 (1979) (upholding Food \& Drug Administration's ban on laetrile).

State constitutional guarantees of individual liberties against infringement by private, rather than state action, whether expressly secured by constitutional language or construed in such a manner by the state supreme court, may run afoul of federal constitutional protections. In other words, state constitutional provisions, like state statutes, may be "unconstitutional" under the Federal Constitution. See, e.g., PruneYard Shopping Center v. Robins, 447 U.S. 74 (1980), in which appellants claimed that the California Supreme Court erroneously construed state constitutional provisions protecting freedom of speech and the right to petition. The court allowed appellees to solicit signatures from passersby on appellants' private property, which appellants claimed violated their rights of due process and just compensation under the 5th and 14th amendments to the Federal Constitution. Similar claims were accepted on state constitutional grounds by the Supreme Court of Washington in Alderwood Assocs. v. Washington Envt'l Council, 96 Wn. 2d 230, 635 P.2d 108 (1981), and rejected by the New Jersey Supreme Court in State v. Schmid, 423 A.2d 615 (N.J. 1980), appeal dismissed sub nom. Princeton Univ. v. Schmid, 455 U.S. 100 (1982).

It is also possible that state constitutional guarantees of individual liberties against infringement by private actors may also conflict with other state constitutional guarantees, such as associational rights, property rights, and due process.

148. See, e.g., Patients, C.T. v. Camden County Bd. of Chosen Freeholders, No. L-33417-74 P.W. (N.J. Super. Ct. Law Div. Jan. 19, 1981). 
mental patients in housing. State courts have a great deal of experience construing state law in zoning cases, and state constitutional guarantees may prove to be the antidote that is needed to remove barriers to the creation of community living arrangements such as half-way houses and residential treatment facilities which are often opposed by local residents and zoning officials acting under municipal ordinances. Although the Supreme Court has not ruled in this particular area, its holding in Village of Belle Terre $v$. Boraas ${ }^{149}$ creates an unfavorable precedent under the Federal Constitution. ${ }^{150}$

Closely related to and often intertwined with zoning issues are claims couched in terms of "least restrictive alternative" which, themselves, are intertwined with right-to-treatment claims. ${ }^{151}$ To the extent that restrictive zoning ordinances, sometimes through thinly disguised means, seek to preclude residential treatment facilities, ${ }^{152}$ they impede the release of patients from psychiatric hospitals or encourage new treatment to commence in an inpatient setting rather than in residential treatment facilities. Thus a court seeking to commit a person to the least restrictive alternative may be stymied by restrictive zoning laws which have impeded the establishment of appropriate alternatives to hospitalization. If the individual is committed to an inpatient setting because of the unavailability of community alternatives, he may not only be denied due process, but he may be denied treatment if the hospital is lacking in staff and facilities and can offer little more than custodial care. The invalidation of such restrictive zoning measures should be approached through arguments based on state constitutional provisions as well as upon federal constitutional claims.

"Equal rights" clauses of state constitutions, especially if they prohibit discrimination on the basis of "health," "illness," or "disability"153 may also prove a fertile source not only for striking down broad restrictions on housing opportunities for mental patients such as are enforced under zoning laws, but perhaps also against individual ${ }^{154}$ instances of housing discrimination-such as refusals to rent, sell, or make mortgages to persons based on past or present mental disability. Such broad constitutional prohibitions on discrimination on the basis of "health," "illness," or

149. 416 U.S. 1 (1974).

150. But see Stoner v. Miller, 377 F. Supp. 177 (E.D.N.Y. 1974).

151. See, e.g., Halderman v. Pennhurst State School \& Hosp., 446 F. Supp. 1295, 1319 (E.D. Pa. 1977), affd in part, 612 F.2d 84 (3d Cir. 1979), rev'd and remanded, 451 U.S. 1 (1981).

152. Such ordinances seek not only to preclude residential treatment facilities for the mentally ill, but also for the mentally retarded, juvenile offenders, and probationers and parolees. See, e.g., City of Pittsburgh v. Commonwealth, 468 Pa. 174, 360 A.2d 607 (1976).

153. There appear to be very few such provisions. In fact, it may be that Illinois is the only state that has one. See ILL. CoNST. art. I, § 19: "All persons with a physical or mental handicap shall be free from discrimination in the sale or rental of property and shall be free from discrimination unrelated to ability in the hiring and promotion practices of any employer." Cf. LA. CONST., art. I, $\S 3$ ("[n]o law shall arbitrarily, capriciously, or unreasonably discriminate against a person because of . . physical condition . . ."); id. $\S 12$ ("[i]n access to public areas, accommodations and facilities, every person shall be free from arbitrary, capricious, or unreasonable discrimination based on . ... physical condition"); IDAHO CONST. art. XI, $\$ 6$.

154. This is certainly so of art. I, $\S 19$ of the Illinois constitution which prohibits certain kinds of discrimination on the basis of "mental handicap," see supra note 153. See Turkington, Equal Protection of the Laws in Illinois, 25 DE PAul L. REV. 385, $391-92$ (1976); Helman \& Whalen, Constitutional Commentary, in ILL. CONST. art. I, $\S 2$ at 109-10 (1971). 
"disability" may, depending on their precise wording, also constitute the basis for litigating employment ${ }^{155}$ and education discrimination claims.

Although the Supreme Court has not dealt with education discrimination against the mentally ill, its decisions in Southeasterm Community College v. Davis ${ }^{156}$ and University of Texas $v$. Camenisch, ${ }^{157}$ involving claims of discrimination on the basis of other kinds of disability with a statutory basis, do not augur well for such litigation brought under a federal constitutional claim. State constitutional provisions could prove to be more useful in establishing such rights too.

A variety of issues involving psychiatric records also lend themselves to potential litigation under state constitutions. ${ }^{i 58}$ Much, though by no means all, of the past litigation in this area has relied heavily upon state statutes, especially cases involving confidentiality of records and the patient's testimonial privilege. Other areas in which there has been some litigation are expungement of psychiatric records, especially where the patient claims that the involuntary hospitalization which was the genesis of the records was illegal and void, ${ }^{159}$ and the right of access to psychiatric records, that is, the patient's claimed right either to read his records, to make a copy of them, or both. ${ }^{160}$

All of these areas lend themselves to litigation under state due process clauses and, where they exist, privacy guarantees, ${ }^{161}$ and in some cases, equal protection clauses. ${ }^{162}$

The need for state constitutional protections in one of these areas-patient access to records - is already well established. Both the trial court and the court of appeals held in Gotkin v. Miller ${ }^{163}$ that a former psychiatric patient had no right under the 14th amendment to inspect and copy the records of her hospitalization. It is not likely that the federal courts will look favorably upon such claims in light of the Supreme Court's position that the 14th amendment creates no property rights in and of itself, ${ }^{164}$ and thus the due process clause confers no protection

155. ILL. CONST. art. I, $\S 19$ ("[a]ll persons with a physical or mental handicap . . . shall be free from discrimination unrelated to ability in the hiring and promotion practices of any employer").

156. 442 U.S. 397 (1979).

157. 451 U.S. 390 (1981).

158. Problems related to the confidentiality of psychiatric records arise in all three phases of patients' rights-the commitment process, involuntary hospitalization, and in the community-and are discussed under the latter aegis primarily for convenience, but also because this is the area in which much of the litigation has occurred because hospitalized patients are often unaware of the problems that their psychiatric records pose for them until they leave the hospital.

159. See, e.g., Wolfe v. Beal, 477 Pa. 477, 384 A.2d 1187 (Pa. 1978).

160. See, e.g., Gotkin v. Miller, 514 F.2d 125 (2d Cir. 1975).

161. See, e.g., Alaska Const, art. I, § 22; ARIz. Const. art. II, § 8; Cal. Const. art. I, § 1; Hawail CONST. art. I, $\S 6$; MONT. CONST. art. II, $\S 10$. Other state constitutions secure a right to privacy in the context of a search and seizure provision and may be of narrower scope in their applicability. See, e.g., Hawali Const. art. I, § 7; ILl. Const. art. I, § 6; LA. Const. art. I, § 5; S.C. Const. art. I, § 10 (1895, amended 1971); WASH. CONST. art. 1, § 7. A state constitutional right of privacy, like the federal right, does not necessarily require an explicit provision in order to be found to exist. See, e.g., In re B., $482 \mathrm{~Pa} .471$, 384 A.2d 419 (1978), discussed infra text accompanying notes 167-68.

162. If a state statute accords certain rights to persons concerning their nonpsychiatric medical records, but not to psychiatric records, the lack of protection accorded the latter might be susceptible to challenge on equal protection grounds.

163. 514 F.2d 125 (2d Cir. 1975).

164. Board of Regents v. Roth, 408 U.S. 564 (1972). 
unless the plaintiff can establish that under state law there is a property right in the psychiatric records. This same problem has arisen in cases of employment discrimination by municipal governments based on mental disability, ${ }^{165}$ and thus relevant state constitutional provisions may prove to be more useful than the Federal Constitution in such litigation as well. And where the party charged with employment discrimination is a private, rather than governmental entity, state constitutional relief may be the sole means of redress. ${ }^{166}$

The usefulness of state constitutional provisions in one of these areas has already been demonstrated in a case, In re $B, 167$ decided by the Pennsylvania Supreme Court involving a testimonial privilege. Although the basis for the holding varied among the several opinions, the opinion for the court relied upon the right of privacy under the Pennsylvania constitution which, like the federal constitutional right to privacy, is not even explicitly referred to in the state constitution. ${ }^{168}$

\section{CONCLusion}

There can be no assurances that state courts-whether on the basis of constitutional, statutory, or common law-will prove to be more hospitable to the claims of persons in the mental health system than the Supreme Court seems to be, nor is it clear that favorable dispositions of such claims is warranted in all cases either as a matter of sound legal reasoning or social policy. Nonetheless, state law-and especially state constitutional law-has been a much overlooked source of substan-

165. See, e.g., Spencer v. Toussaint, 408 F. Supp. 1067 (E.D. Mich. 1976). But cf. Doe v. Syracuse School Dist., 508 F. Supp. 333 (N.D.N.Y. 1981) (injunction against inquiry about treatment for mental illness in statutorily based suit).

166. If the private employer is a federal contractor or receives federal financial assistance, employees or potential employees who suffer discrimination on the basis of "handicap" may have a basis for relief under the Rehabilitation Act of 1973, 29 U.S.C. $\$ \S 793,794$ (1976 \& Supp. II 1978). Whether or not there is a private cause of action under this act is unsettled. See supra note 145 . There may, of course, be grounds for relief under state statutory as well as constitutional law.

167. 482 Pa. 471, 394 A.2d 419 (1978).

168. This is a very confused opinion. First, it takes something akin to higher mathematics to determine which justices concurred in the reasoning of the court's opinion and which merely concurred in the result for other (nonconstitutional) reasons. Once that question is resolved, the opinion must be read carefully to determine whether its basis is the federal or the state constitutional right of privacy. The court spends a good portion of the opinion discussing the federal constitutional right of privacy and citing and analyzing United States Supreme Court cases dealing with the right. See $471 \mathrm{~Pa}$. at 481-82, $394 \mathrm{~A} .2 \mathrm{~d}$ at 423-24. It then discusses the tort, rather than the constitutional, right of privacy as it has developed in the Pennsylvania courts. $471 \mathrm{~Pa}$. at 482-84, $394 \mathrm{~A} .2 \mathrm{~d}$ at 424-25. Then the opinion "conclude[s] that in Pennsylvania, an individual's interest in preventing the disclosure of information revealed in the context of a psychotherapist-patient relationship has deeper roots than the Pennsylvania doctor-patient privilege statute, and that the patient's right to prevent disclosure of such information is constitutionally based." $471 \mathrm{~Pa}$. at $484,394 \mathrm{~A} .2 \mathrm{~d}$ at 425 . Brief mention is then made of the federal right, with a reference to Griswold $v$. Connecticut, and then a somewhat brief, though detailed, enumeration is made of those provisions of the Pennsylvania constitution from which this "penumbra[I]" right "emanates." Id.

When all is said and done, it is not entirely clear that the Pennsylvania constitution is the basis of the holding. Certainly the West Publishing Company employees who furnish the headnotes are not clear about this. Id. at 420 (headnote 9).

All of this might have been prevented had petitioner's counsel-among whom, sadly, the author is to be counted-better raised and briefed this issue, rather than merely mentioning it in a footnote. Brief for Appellant at 21, n.9. 
tive rights for persons in the mental health system, and lawyers representing such persons plainly have a duty to raise state law claims along with the federal law claims that they have been pursuing for a decade or more. Although there is no guarantee that all such efforts will (or ought to) be successful, state law claims will undoubtedly be successful in some cases where federal claims will fail. With this in mind, any lawyer representing persons in the mental health system has a professional responsibility ${ }^{169}$ _and possibly a legal one ${ }^{170}$ - to raise such claims.

169. See ABA Code of Professional Responsibility, DR 7-101(A)(1) (1980) ("A lawyer shall not intentionally [f]ail to seek the lawful objectives of his client through reasonably available means permitted by law...").

170. See, e.g., State ex rel. Memmel v. Mundy, 249 N.W.2d 573 (Wis. 1977); In re Hutchinson, 421 A.2d 261 (Pa. Super. 1980). 